\title{
The Responsibility System in Agriculture
}

Its Implementation in Xiyang and Dazhai

\author{
TANG TSOU \\ University of Chicago \\ MARC BLECHER \\ Oberlin College \\ MITCH MEISNER \\ Ann Arbor, Michigan
}

In the post-Mao years, particularly since the Third Plenum held in December 1978, China has undertaken a series of reforms in virtually all spheres of political, economic, social, and cultural life. Of all reforms, the most profound and rapid have been those in the policies, institutions, and practices in the countryside. In no other sphere has political control by the upper levels been relaxed to a greater extent; nowhere have relative autonomy and freedom in managing economic affairs on the part of the lowest-level units, the households, and the individual producers been restored more quickly; and nowhere have the market mechanism and individual incentives been given a more important place within the overall

\footnotetext{
AUTHORS' NOTE: Tang Tsou wishes to acknowledge the support of the National Endowment for the Humanities for the research project "Political Leadership and Social Change in China at the Local Level From 1850 to the Present." Marc Blecher acknowledges support from the Committee on Research and Development and the Social Science Data Lab-especially Ed Wilson-of Oberlin College.
} 
framework of national planning. In no other period since 1955, including the three years of agricultural crisis, has the Party Center as a matter of long-term policy accorded households and individual farmers a greater role.

Moreover, these changes have reflected more directly and visibly the wishes of the individuals concerned than in most other fields of social life. They have been the products of a complex process, combining the flow of influence from the bottom to the top and from the top to the bottom. This process has included the official acceptance and then encouragement of many practices adopted by the peasants themselves but previously concealed from officials at the higher levels. It has involved much spontaneous experimentation by peasants and low-level cadres in various localities. It has not been dominated by a single official or a few officials at the highest level of the Party. Indeed, it began as an opposition to the Maoist movement to learn from Dazhai and to build Dazhai-type counties by a combination of forces: peasants in many localities; local officials at various levels up to and including provincial first secretaries (notably those at Anhui and Sichuan); economists, intellectuals, economic planners, and officials engaged in agricultural work as well as top party leaders such as Deng Xiaoping and Chen Yun. Despite their shared opposition to the Maoist model, as might be expected, the reformers were not of one mind. Some wanted to push change as far and as rapidly as possible. Others were more concerned with preserving some basic features of the collective system. Many ideas and proposals were advanced and debated. Ultimately, those ideas and proposals which were believed to have produced concrete results in increasing production and improving the peasants' livelihood were adopted. The discovery of new problems which have emerged in the aftermath of the changes has led to the search for new solutions and thus to another round of discussions and debate.

In institutional terms, the central feature of these changes is the evolution of the system of responsibility for agricultural production. This evolution represents not only a change in the method of labor management but also an adjustment in relations of production while maintaining the system of collective ownership 
of land and other major means of farm production. It involves the most significant change in the direction of developments in the countryside since the beginning of collectivism in 1953, the rapid drive toward cooperativization in 1955, the communization movement in 1958, the launching of the movement of learning from Dazhai in 1964, and the official proclamation in 1975 of the movement to build "Dazhai-type counties." It may lead to a change in the system of the commune, at least to the extent of making it purely a unit of collective economy, while reestablishing a parallel unit for governmental administration at similar levels. ${ }^{1}$ From a larger historical perspective, it can even be said that the regime has gone as far as it can in readopting some of the traditional forms of farm practices and relations of production short of dismantling the system of collective economy established since 1953.

The adoption and evolution of the system of responsibility for agricultural production represents the very antithesis of the movement to learn from Dazhai and to build Dazhai-type counties. The latter movement was in essence an attempt to revitalize the commune system and to encourage a trend toward increasing the size and functions of collective units and minimizing the role of the individual outside the strictly defined collective framework. This was a political movement in which political power and mass mobilization were used to bring about economic development and equality. In contrast, the responsibility system seeks to appeal to the economic self-interests of the individual peasants. Dazhai was held up as a single model for emulation throughout the nation; now the development of a multitude of institutional forms and practices which fit the variations in the Chinese countryside is encouraged. In short, Dazhai as a model was proclaimed to be applicable everywhere and its "success" was trumpeted loudly. Now the tumult to "learn from Dazhai" and to "build Dazhai-type counties" has ended and the Party Center has sanctioned something very different. This article seeks to give an account of the evolution of rural policies since 1977 and a description of the responsibility system. It then looks at how the recent policies of the Party Center have affected policies, institutions, and practices in Xiyang county and Dazhai brigade on the 
basis of materials gathered during a brief stay in Xiyang county in August 1980.

In 1977, when outwardly the Dazhai movement reached its zenith, an undercurrent of opposition was already rapidly developing. In two meetings in November and December 1977, opponents stressed the importance of respecting the autonomy of the team; reorganizing the system of management of the communes, brigades, and teams; correcting "equal divisionism" in the distribution of rewards; reviving the system of awarding work points according to fixed quotas of work; protecting private plots; and promoting household sideline occupations. But these proposals were easily suppressed by the highest authorities in charge of agriculture, presumably Ji Dengkui and Chen Yonggui with the support of Hua Guofeng. ${ }^{2}$ The turning point was marked by the Third Plenum after a shift in the balance of political forces had been registered in the victory of the reformers in the debate over the epistemological postulate that "practice is the sole criterion for testing truth." That postulate played a prominent part in undermining the Maoist orthodoxy as it had developed during the Cultural Revolution, in destroying the "two whateveris $m$," and in paving the way to a reevaluation of the role of Mao in governing China after 1949.

The Third Plenum agreed to distribute to the lower-level units for discussion and trial use two decisions: "Decisions on Some Questions Concerning the Acceleration of Agricultural Development (Draft)" and "Regulations on the Work in Rural People's Communes (Draft for Trial Use)." The first document of 25 articles still reaffirmed the mass movement to learn from Dazhai and to build Dazhai-type counties. It told the cadres and peasants to continue to uphold the "basic experience" of Dazhai, but this was now defined merely as the "revolutionary experience of self-reliance and hard struggle." At the same time, it strongly urged them to implement firmly the Party's agricultural and rural economic policies and to learn from useful experiences at home 
and abroad. It foresaw the emergence of many new models. Dazhai and all the other advanced units of the nation were told to recognize their own shortcomings as well as achievements and to score new successes and create new experiences.

Although the movement to learn from Dazhai was reaffirmed, many of the Party's concrete policies on agriculture and the rural economy as mentioned in the 25 points ran counter to the specific features of the Dazhai-Xiyang model. Point 3 urged collective units at all levels to implement the principle of distributing rewards in proportion to work done and to correct firmly the mistake of "equal divisionism." It stipulated that "giving work points according to fixed work quotas is permitted and giving work points according to time spent plus appraisal of work done is permitted." Significantly, it added that "under the prerequisite of unified accounting and unified distribution by the production team, [the method of] assigning responsibility for work to work groups, calculating rewards for work by linking them to yield [obtained by the work group], and giving bonuses for surpassing output-quotas [baogong dao zuoye zu, lianxi chanliang jisuan laodong baochou, shixing chaochan jiangli] is also permitted." (Zhonggong yanjiu, May 15, 1979: 154; italics added). ${ }^{3}$ Implicitly, it discouraged the use of the Dazhai method of "self-assessment and public discussion" and the method of "giving fixed workpoints inflexibly" to the peasants for putting in a day of work. At the other extreme, it specifically prohibited assigning responsibility for production to the household [baochan daohu], but this was to gain approval as one of the major forms of the responsibility system within two years. It also proscribed the division of land among households for individual farming [fentian dangan]. This latter proscription remains in force with very minor exceptions-for example, in isolated areas in Tibet.

The general and broad provisions in the draft document of 25 articles were not specific enough to guide the development of new institutions and practices. Almost immediately, they were given different interpretations by cadres and peasants in different localities. A debate raged over what was "also permitted" under the phrase, baogong daozu. The narrow interpretation supported by the editor of Renmin ribao (March 15, 1979:1) in a comment in 
a letter to the editor printed on the front page on March 15, 1979 was that baogong daozu should be construed as the assignment of responsibility for day-to-day field management to the work groups but not as identical with baochan daozu (assignment of responsibility for production to the work groups), accompanied by the allocation of a specific portion of land, farming implements, and draft animals to the latter for their use. Baochan daozu should not be permitted. For under the system of baochan daozu, many work groups had become in effect "small teams" which took on the character of accounting units, and the team had degenerated into an empty shell.

The broader interpretation was adopted in Anhui. Under this interpretation, baochan daozu was considered not essentially different from baogong daozu. Under the system used in Anhui, each work group had the authority to use a fixed amount of land and a fixed number of draft animals and farm implements, but it did not own them. The teams still made a unified plan for cultivation and practiced unified distribution of the produce and cash at the end of the harvest. How this system worked can be seen in our later discussion of the system used in Zhujiazhuang work group in Xiyang county.

This interpretation was advanced by an official of the Agricultural Commission of the Anhui provincial government in a letter to Renmin ribao. Apparently the situation was in flux. At the end of the month, the editor of Renmin ribao recognized baochan daozu as one form of the system of linking rewards to yield and expressed the view that it should be permitted to continue until the final outcome could be determined. But he still opposed giving the work groups all, as distinguished from a specified percentage, of their above target yield as bonuses (Renmin ribao, March 30, 1979: 1). Even so, the first comment of only a few lines by the editor aroused widespread fear and uncertainty among local cadres and peasants that the Party Center was once again changing its policies and reversing the trend toward liberalization and relaxation of political control (Renmin ribao, July 2, 1981: 4; Interview in Chengdu, August 1980) - a fear and uncertainty which haunted Chinese in all walks of life. 
Anhui scored at least a partial victory over the editor of Renmin ribao, whose comment presumably reflected the view of Wang Renzhong, who had replaced Ji Dengkui as the official in charge of agriculture and who was to be replaced in that position by Wan $\mathrm{Li}$, the first secretary of Anhui, a year later. Anhui rested its case on the argument that the peasants in various localities in the provinces were experimenting with diverse forms of the system of responsibility and that whether these forms could promote production could be determined through "practice," thus appealing to the epistemological postulate as their ultimate justification. Moreover, that abstract postulate and the whole atmosphere of relaxation of centralized, upper-level political control legitimized the frequently concealed practices of the peasants which contravened the official policies on work management. It also encouraged a measure of spontaneity in the search for forms of organization and management most suitable to local conditions. In many cases, these forms were first developed by peasants and lowestlevel cadres behind the backs of higher-level officials and only later gained the approval of cadres at the county and provincial levels. Finally, they were sanctioned by the Party Center.

Thus, development of the system of responsibility was partly the outcome of an unorganized movement from the bottom to the top. In five districts ${ }^{4}$ south of the Yellow River and astride the Huai River in the provinces of Anhui, Henan, and Shandong, the greater part of the teams adopted the system of baochan daozu in 1979, while a very small part of the teams spontaneously developed the system of baochan daohu (assignment of responsibility for production to the household) (Renmin ribao, January 23, 1981: 2). As early as 1978, ten teams in one county adopted the system of da baogan daozu (Renmin ribao, January 28, 1981: 1); in Fengyang county in Anhui, $83 \%$ of the teams adopted this system in 1979 , which we shall discuss later.

When the Fourth Plenum adopted the final version of the document of 25 articles in September 1979, it deleted the flat prohibition of baochan daohu. In its stead, it declared that "except for certain sideline occupations with special needs and isolated, single households living in remote hilly areas without 
easy means of transportation, the system of baochan daohu should . . . not be used" (Renmin ribao, October 6, 1979: 1). It retained the same language when referring to the assignment of responsibility for work to work groups. It deleted the statement in the draft document that "they [party committees at all levels] must continue to grasp well the mass movement to learn from Dazhai and to popularize Dazhai-type counties." It merely urged them to continue to guide the vast number of cadres and peasants in learning from the "basic experience" of Dazhai, which was now defined in the words of Zhou Enlai rather than the modified formulation widely used during the Cultural Revolution. This change represented the formal termination of the movement to build Dazhai-type counties, after that movement had, for all practical purposes, ceased some months earlier. All this suggests that the impulse for the development of new forms of the responsibility system and their progressive spread came from the bottom and percolated to the top with the indispensable support and championship of Party leaders at the national and provincial levels. As two correspondents of Renmin ribao (July 2, 1981: 5) put it, the special feature of this development was that "the bottom level pushes the upper level and the masses push the cadres."

But one should also not overlook the fact that it was the top leaders who set the tone for reform and created the atmosphere 5 which emboldened the peasants to revive-at first stealthily and later openly - the practices engaged in by some of them in the three years of agricultural crisis, developed first in the early days of the cooperativization drive in 1953 and rooted in the rural tradition. In this atmosphere of reform and relaxation of control, the peasants and lower-level cadres revived many old practices and developed new ones in concrete detail, which were then officially sanctioned by the Party Center in general terms after a period of debate and experimentation.

The permission given by the Party Center in the finalized document to baochan daohu as an exception gave a measure of legitimacy to this form of responsibility system. Its effect was to encourage the peasants to extend the use of this system in localities where economic conditions were very poor, where the 
collective system was not functioning well, and where the cadres gave themselves excessive work points without effectively discharging their duties to the collective and without doing a fair amount of farm work. As early as 1978, a commune in Yijun county of Jiangxi adopted the system of baochan daohu for the day-to-day management of a newly developed wheat field of 4000 $m u$ (Renmin ribao, April 7, 1981: 2). In many counties-for example, one each in Anhui, Hunan, and Shandong and three counties in Guizhou-baochan daohu was widely used (Renmin ribao, November 5, 1980: 2). In 1979 and 1980, more than $70 \%$ of the teams in Funan county of Anhui also adopted it. Many of the teams in these counties are located not in hilly areas but in the plains.

Moreover, a system of devolving responsibility to individual farm workers developed spontaneously, although the teams under unified management still perform collectively many indispensable functions for the individual farm workers. The first and most popularized case was the Mengjiaping team in Shanxi province. Allegedly created in the spring of 1979 by low-level cadres, this system was known as "division of work according to specialization and assignment of production responsibility to an individual farm worker." In 1979 and 1980, this system, with some variations, was used in a number of teams in widely scattered parts of China. We found reports of its existence in Shaanxi, Liaoning, and northern Jiangsu (Renmin ribao, November 5, 1980: 2, December 13, 1980: 1, December 24, 1980: 2). This system was gradually perfected and widely popularized in Henan in 1979 and 1980 under the simplified name of lianchan daolao (linking production quotas to an individual farm worker). By 1981, it was used in $55 \%$ of the teams there (Renmin ribao, February 24 , 1981: 2). Finally, a new form combining elements of the previous methods developed. This form is known as zhuanye chengbao, lianchan jichou (contract work for specialized tasks, calculating reward by linking it to yield). In sum, it is obvious that peasants and low-level cadres have taken advantage of the changes in Party Center policies to develop and extend new forms of the responsibility system which yield greater autonomy and promote local self-interest. 
Meanwhile, the Fifth Plenum in February 1980 witnessed not only an important shift in top personnel but also the most significant restructuring of organization of the Party Center since 1976. The Secretariat, which had disintegrated during the Cultural Revolution, was reestablished with $\mathrm{Hu}$ Yaobang as General Secretary; he was to replace Hua Guofeng as Chairman of the Party 14 months later. Wan Li, the first secretary of Anhui province, was appointed one of the 11 members of the Secretariat. He was put in charge of agriculture. In discussing its reestablishment, Ye Jianying described the Secretariat as an organization which "stood in the first line [of work] with the Politbureau and its standing committee in the second line" (Liaowang, April 20, 1981: 9). There is no doubt that the Secretariat soon became the most active (usually it meets twice a week) and effective of all organs in promoting reforms in every sphere. After the reorganization, the Party Center, with the Secretariat as its prime mover, took a series of bold steps. These included a proposal to tackle the economic and political problems of Tibet, a recommendation to reconstruct Beijing, and exposure of the case of the sinking of an offshore oil drilling rig.

Insofar as rural policy is concerned, the Center took two big steps. The first was to launch open criticism of Xiyang county and its responsible person, Chen Yonggui, which led to his resignation as Vice-Premier in September. The other was to send top Party leaders to investigate conditions in the rural areas of several provinces and to commission more than 100 officials engaged in rural work, economists, and theoreticians to study typical localities in ten provincial-level units. These investigations culminated in a symposium held in mid-September in Beijing and attended by the first secretaries of all the provinces, cities, and autonomous regions. The conclusions of this symposium were summarized in a document known as "Certain Problems Concerning Further Strengthening and Improvement of the Responsibility System for Agricultural Production."6 On September 27, this summary was sent down by the Party Center as document number 75 to the Party committees and groups of leading Party members at the next highest level. This document's adoption was 
considered by the Beijing Review the sixth of ten major events in China in 1980.

Document No. 75 approved baochan daohu (including baogan daohu) as a "necessary measure" in developing production and maintaining links with the masses, not only in remote hilly areas but also in poor and backward regions. But teams in ordinary areas where the collective economy was relatively stable, production was developing, and the masses were satisfied with the responsibility system currently in use were still told not to use baochan daohu. Teams which had already adopted baochan daohu were allowed to continue it so long as the masses did not demand a change. As for those communes, brigades, and teams where economic conditions and management were in the "middle range," they were directed to use a variety of measures to solve their problems rather than confine themselves to baochan daohu alone. The document stressed the merits of zhuanye chengbao, lianchan jichou, as well as the system of lianchan daolao in dayto-day field management. Essentially, the Party Center gave its stamp of approval to the various forms of responsibility system developed spontaneously in different localities, although it had its preferences among them. The fundamental spirit underlying the document was to permit the coexistence of a variety of forms of responsibility system within one area, one commune, or even one team and to allow the team the autonomy to choose among them according to objective conditions and its capacity for managing collective farm work. Implicitly, it also allowed a team to use one form of the responsibility system to govern the relationship between it and its work groups and another form to govern the relationship between the work group and the individual peasants. The dispatch of this document downward had the effect of stabilizing the peasants' and low-level cadres' expectations, but it has not prevented them from further trying various methods to improve their own livelihood.

On March 30, 1981, the Party Center and the State Council jointly issued a circular to transmit a document drafted by the State Agricultural Commission entitled "a Report Concerning Vigorous Development of a Diversified Economy in the Rural 
Areas" (Banyue tan, April 25, 1981: 13-14). Both the circular and the document insisted there should be no relaxation of efforts to increase grain production. But their emphasis was clearly on the importance of developing a diversified rural economy by expanding animal husbandry, fishery, forestry, fruit trees, and many sideline occupations. For this purpose, it authorized the expansion of private plots (including plots to produce feed and fodder for animals) up to a maximum of $15 \%$ of the total cultivated area of a team. ${ }^{7}$ Even more surprising to outside observers, it gave approval to what the masses called ziliu ren-that is, persons who do not participate in collective farm work and do not draw grain rations from the team but who work only on their private plots and sideline occupations (Banyue tan, April 25, 1981: 14, 20). ${ }^{8}$ The explicit permission given to individuals to be ziliu ren, or selfemployed persons, goes one step further in granting greater freedom to peasants in managing their own economic affairs than the practice, proscribed under the Dazhai model but adopted nonetheless by many teams, under which peasants engaged in transport, handicraft, and similar work in nearby towns and cities receive their grain ration from the team and in turn pay the team a fee out of the cash earned. The report and the circular also sought to promote the development of a diversified rural economy by adopting new proposals of agronomists and economists. These documents at once reflect the state of scientific knowledge in China and urge its use in promoting agricultural development.

\section{A SCHEME FOR CLASSIFYING VARIOUS FORMS OF THE RESPONSIBILITY SYSTEM}

All four documents mentioned so far use terms which are not fully defined and which in practice refer to quite different types of arrangements. Reports and articles in newspapers and periodicals are of some help in describing and classifying the variety of forms included under the rubric of "responsibility system," but unfortunately, not even these sources contain all the information necessary, nor do they use the terms consistently. Thus, in piecing together the information from these sources, we sometimes had to 
fall back on our interpretation of the terms used and our judgment of what the authors meant. A short visit to the villages provides more detailed and concrete information, but a single visitor on a hectic trip is likely to miss important bits of information. Fully realizing all these shortcomings, we have attempted to do our best.

The term "responsibility system" (zeren $z h i$ ) encompasses a wide variety of forms. ${ }^{9}$ What it definitely excludes, at the one extreme, is the "self-assessment and public discussion" method of awarding work points. It is also distinguishable from the system of "fixed [or basic] work points given inflexibly" to the peasants for putting in a day of work (sifen siji or difen siji), as well as the system of basic work points plus flexible appraisal (difen huoping). These three systems of distributing rewards are believed ineffective in establishing a direct and visible link between work and compensation, thus creating a drag on the productivity of the individual peasant and making management of collective farming a matter of constantly issuing commands and close supervision. At the other extreme, division of land for individual farming is not considered a form of the responsibility system. These two extremes mark its boundaries.

The various forms of the responsibility system differ according to the degree to which they directly and effectively link the individual peasant's reward and self-interest with his or her work, though obviously the question of effectiveness must be somewhat conjectural and subject to further examination. Some of these forms were developed as far back as the beginning of the cooperativization movement in 1953. Others were adopted in some localities at one time or another since the establishment of the advanced agricultural producers' cooperatives in 1956-1957. Still others are new. Some emerged or reemerged spontaneously at the grass-roots level since 1977 and were later approved by the authorities at the county, provincial, and national levels.

The forms of the responsibility system can be classified in a number of ways, but basically they involve two logical components. ${ }^{10}$ One of these pertains to the way individuals are remunerated for their labor within any relevant group that shares the responsibility of an assigned task or tasks and where the 
responsibility is not further devolved to the household or individual. The second involves the level of assignment of responsibilities for production and the methods for regulating the assignment and concomitant economic exchanges between the assigning body (usually the production team and, in a small number of cases, the brigade) and the relevant responsible group or party (that is, a single household or an individual).

In reference to the methods of individual remuneration for labor, the first form to be practiced on a large scale and officially promoted after Mao's death was the awarding or scoring of work points according to fixed work quotas (ding e jigong). For example, a peasant who transplants rice seedlings in one $m u$ of land earns a specific number of work points. In many places there are roughly 300 different quotas for agricultural production activities." Thus, the "basic work point" is eliminated, and "taskrate" is in effect substituted for time worked. ${ }^{12}$ This system (also known as ding $e$ jichou and ding $e$ baogong) was first officially authorized and sanctioned in Anhui in November 1977, although it had been used earlier in various parts of China without much publicity. In a refinement of this system, fixed work quotas can also be assigned to a series of tasks related to each other at one time or in a series of steps. This is known as xiaoduan baogong, ding e jichou. A system of management using one or both of the methods described above is called management by fixed quotas (ding e guanli). ${ }^{13}$ At the end of 1980 , this system was used in $50 \%$ of the teams in China for day-to-day field management (Renmin ribao, December 2, 1980:3).

The responsibility system implies that production responsibilities can be assigned by a larger collective unit to a smaller subgroup or party. There are three possible levels of devolution of responsibilities for production tasks depending on the size of the subgroup. The first level involves the division of a production team into work groups. This division makes the collective unit of responsibility smaller and is an important first step in relating work performance and rewards more directly (in addition to reforms in individual labor remuneration procedures), in making 
supervision more intimate and easier, and in ameliorating the problem of the "free ride."

At this level, there are three subtypes. The first operates in the following manner. The production team can define for a work group its task (output quota), the standard of quality of its produce, and the time limit in which the task is to be completed. In return, the team gives a specific number of work points to a work group for the completion of this task according to the specifications. The work group will distribute the total work points received to its individual members either by an appraisal of their work performance or according to the fixed work quota which they have fulfilled. This subtype is called "one work group with four specifications" (yizu siding). ${ }^{14}$ Under this system, the peasants' reward is linked with output, although still quite indirectly. ${ }^{15}$

In the second subtype, the relationship between the production team and its work groups undergoes an important change, incorporating an element essentially the same as that used in the system of sanbao yijiang adopted in some of the cooperatives in the period between 1953 and 1956 and later during the last two years of agricultural crisis, 1960 and 1961. This element is the provision of a bonus or a penalty for the overfulfillment or nonfulfillment of the obligations specified in an agreement or contract between the team and the work groups. The number and content of these obligations vary from place to place. A common form is siding yijiang (four specifications and one bonus).

Under this system, the work group guarantees the fulfillment of a fixed quota or value of agricultural output at a fixed cost, while the team assigns a fixed number of workers to the group and promises to give the group a fixed number of work points. If the group obtains a higher yield than its output target (presumably staying within the limit of cost), it will have a bonus; but if it fails to reach the target, it will have to pay a penalty. The bonus or penalty is calculated in terms of the percentage of above-target yield or shortfall, but the percentage given to the work group as a bonus is usually higher than the percentage of shortfalls paid by 
the work group as a penalty. Bonuses can be as high as $80 \%$ or $70 \%$; the penalty can be as low as $20 \%$ to $30 \%$. In case of drought or flood, the penalty is usually waived or reduced, depending on the seriousness of the natural disaster.

In spite of the division of the team into work groups, the team remains the basic accounting unit. It adopts a unified production plan for the whole team. It allocates labor power among the work groups. It fixes the workday value or the work point value for the whole team on the basis of the value of agricultural output (which is handed over by the work groups) after deducting taxes, expenses, accumulation funds, welfare funds, and other levies. It gives the bonuses or penalties to each work group by increasing or decreasing the workday value of the members of that particular work group. Thus the system of unified distribution of rewards by the team is preserved. The relationship between the work group and the individual peasants is governed by one or the other method of ding e guanli mentioned above, or both in various combined forms. In some localities, this second subtype is called assignment of output quotas to each work group (baochan daozu). ${ }^{16}$

In the third subtype, all above-target yields belong to the work group, while all shortfalls must be made good by the group from its grain reserve and that of its members. It was the use of this subtype which was disapproved by the editors of Renmin ribao as late as March 30, 1979.

The fourth subtype, to which the term baochan daozu is also applied, is more accurately called in some localities "contract work in a big way" or "assumption of total responsibility" (da baogan) by the work group. The most publicized case of a county using this form is Fengyang, Anhui, which has long been known for its poverty. In this specific case, a contract is concluded between a team and each of its work groups. A work group guarantees to fulfill the production plan, fill the quotas of farm and sideline products to be sold to the state, and turn over certain amounts of accumulated funds and other levies to the team. After having discharged these obligations, the work group retains all 
other produce for distribution among its members. But it must also make good all shortfalls. Although the team provides guidelines for the distribution of rewards by the work groups among the members, unified distribution which obtains in the second and third subtypes is not practiced.

Fengyang began to use this system in 1978, without the official sanction of the Party Center but with the support of the Party secretary of the county. In $1979,83 \%$ of the teams in that county adopted this system; in 1980, $93 \%$ did so (Renmin ribao, January 12, 1981: 4, January 28, 1981:1). The distribution of rewards by a work group to its members is still handled either under the system of appraisal of work done or under the system of rewarding work points according to fixed work quotas.

Devolving production responsibility to the level of the work groups below the production team has generally gone by the designation of baogong daozu or baochan daozu (fixing work or production responsibility for each work group). It should be recalled that both the draft document on the acceleration of agricultural development adopted by the Third Plenum in December 1978 and the definitive document adopted by the Fourth Plenum in September 1979 permitted almost as an aside the adoption of the first two subtypes ${ }^{17}$ but were silent on the third and the fourth. But toward the end of 1980, all four subtypes were promoted by the authorities and widely used in various parts of the country.

Baochan daozu represents another step toward a more direct and effective linkage between an individual peasant's reward and self-interest and his or her work. But in various localities, this linkage is still considered insufficiently direct. Moreover, if team management is not strong enough, the work groups become in effect basic accounting units, while the production team loses its essential functions to the groups.

Hence in some places, the number of teams using the system of baochan daozu decreases as time goes by, and responsibility is devolved to still lower levels: the household and individual (Renmin ribao, March 7, 1981: 2). In Fengyang, Anhui, for 
example, since 1981 responsibility is being further devolved from the work groups to the households.

In this scheme, production tasks are assigned to the household; production and payment arrangements are made with it. This is the second level of the devolution of responsibility. It is known as the assignment of production responsibility to the household or the household responsibility system, baochan daohu. ${ }^{18}$ There are three subtypes at this level. Under the first, output quotas for only specific kinds of produce are assigned to the household. Under the second, all the land belonging to a team and the output quotas for all farm produce are assigned to households. In both of these subtypes, the team still retains its function of unified accounting and distribution. A system of bonuses and penalties is used. Under the third, the household retains all its produce after paying taxes and selling its grain to the state under the system of unified purchase and after handing over to the team its share of collective accumulation and welfare funds, as well as other levies. This is known as assumption of total responsibility by the household, or household total responsibility system, baogan daohu, which is also called da baogan but must not be confused with da baogan by the work group. Da baogan by either the work group or the household is based on the same principle of incentive (similar to that contained in the agricultural tax system that freezes obligations at fixed amounts of produce calculated in terms of the low yields of the early 1950s): the fixed floor of obligation is an incentive to produce as much as possible above that amount. The government recognizes that this subtype seems to be a step backward from the system used in the advanced agricultural producers' cooperatives. But it stresses that this can bring into play the activism of the peasants and encourage them to cultivate their land meticulously and obtain greater yields (Renmin ribao, November 1, 1980: 1). Twenty percent of the teams throughout China use one of these three subtypes of fixing output quotas for each household (Renmin ribao, November 5 , 1980: 2), a practice which was used in some localities in China during the three years of agricultural crisis but which was banned and condemned from 1964 to late 1977 or early 1978. 
Baochan daohu was at first used where the peasant households belonging to a team are widely scattered in relatively poor hilly regions. ${ }^{19}$ But there has been a tendency for this form to spread to areas where teams are badly managed or led, peasants are very poor, and agricultural production stagnant. This tendency has been not only permitted but even encouraged by the government in some provinces. As noted earlier, in Funan county in Anhui province, more than $70 \%$ of the teams have adopted this system. A two-part dispatch in Renmin ribao (January 22, 1981: 2, January 23, 1981: 2) gave strong endorsement to the widespread use of this system in five districts in Anhui, Henan, and Shandong. Through the mouths of the local authorities or in their own words, three correspondents of the Xinhua news agency asserted that of all forms of the responsibility system, baochan daohu establishes the most direct link with the peasants' interests, makes their responsibility most concrete, and is the easiest method to use. For these reasons, it was said to be very appealing to peasants living under straitened circumstances. It sprang up spontaneously in 1979 in five districts. In 1980, it spread rapidly and has become a major form of the responsibility system there. ${ }^{20}$ Baochan daohu, including da baogan, is now regarded not as a mere expedient to overcome poverty but as a "positive measure" to promote production (Renmin ribao, August 4, 1981: 2).

In a commune in Jiashan county in this region, some single households, some groups of three or four households, and some work groups have used their own savings to purchase walking tractors (Renmin ribao, December 20, 1980: 1). Thus, this important and very expensive farm implement used at the lowest level can now be privately owned. In Guizhou, in 1980 a production team adopted the system of baochan daozu but supplemented it with an allocation of some of its land to the households for production of their grain rations (Renmin ribao, December 21, 1980: 3). This is termed kouliang tian.

The third level of assignment that has appeared in recent experiments with the responsibility system is the fixing of output quotas for an individual farm worker, baochan daolao. An example of this form was given in Renmin ribao and has been 
mentioned in passing above. The Mengjiaping team in Shanxi had only 16 households, and a population of 64, including 12 male and 8 female farm workers. Its $310 \mathrm{mu}$ of cultivated land were divided in 1979 into eight parts. Eight experienced male farm workers were selected and each was assigned to cultivate one of the eight parts of land under a contract. Each of the eight farm workers was obligated to produce $6,500 \mathrm{jin}$ of grain for the collective (that is, 168 jin per $\mathrm{mu}$ ). Everything produced above this quota belonged to him, but he also had to make up for all shortfalls from his private reserve (Renmin ribao, September 28, 1980, October 13, 1980: 1). ${ }^{21}$ The remaining farm workers were assigned other kinds of specific jobs such as raising goats and basic farmland construction.

The system of baochan daolao has been further refined, specified, and developed into lianchan daolao. A description of this system was given in Renmin ribao. Of the 370,000 teams in Henan, about $60 \%$ have adopted this system (Renmin ribao, February 24, 1981: 2, March 7, 1981: 2; article by commentator, March 2, 1981: 1). According to these reports, this system has a dual advantage. On the one hand, it preserves the integrity of the team as the basic accounting unit, without any division into work groups. On the other hand, it links the individual peasant's reward most directly and effectively to his or her work. The team undertakes unified planning, unified tilling of the land, unified investment, and unified allocation and employment of labor, draft animals, and farm machinery and tools of large and medium sizes. All farm tasks that are not easy for the individual peasant to do are done by the team, which organizes persons with specialized skills or small groups to undertake these tasks, which include ploughing, harrowing, raking the soil, building ridges for vegetable gardens, sowing, irrigating the fields, insect control, nursing seedlings, and basic farmland construction. The daily management of the fields throughout the year is assigned to individual farm workers. Each is held responsible for managing a specific sector of the land for one to three years. The worker is obligated to fulfill a production quota, which is generally fixed on the basis of the output of the last year prior to the implementation of this system. The peasant is provided with a fixed amount of chemical 
fertilizer, insecticides, seeds, and other material inputs and is given a fixed number of work points for the accomplishment of the assigned tasks. But there is also a provision for bonuses for overfulfillment of the production quota and penalties for nonfulfillment. The system under which the farm worker receives a bonus equal to all the above-quota yield and pays the full penalty for the shortfall has gradually replaced the system under which he or she receives a bonus equal to a proportion of the above-quota yield and pays a penalty equivalent to only a proportion of the shortfall. In case of natural disaster, bonuses and penalties are calculated in terms of production quotas readjusted according to the seriousness of the loss. This system has been clarified and stablized after the Party Center's directive on the responsibility system in rural areas was sent down in September 1980. An important article by the commentator of Renmin ribao suggests that this system is most suitable for those communes and teams which are neither very poor nor very rich (Renmin ribao, March 2, 1981: 1). ${ }^{22}$

In Tibet alone peasants in isolated areas who are confronted with great difficulties are officially permitted to "go it alone" (dan gan). Under this subtype, an individual household has no obligation toward the collective unit. It owns its means of production and bears the responsibility for its own profits and losses (Renmin ribao, November 15, 1980: 1).

As we move down the levels of the responsibility system, beginning with those teams which still manage production and pay workers according to the task rate or "ding e" system, to the various subtypes of work group responsibility, then to the level of the household, and finally to the level of the individual worker, the linkage between individual effort and reward would appear to be progressively more direct and visible. (This point is somewhat obscured at the household level, since household management of internal work and pay relations becomes a more private matter; the link between individuals within the household and household management of the responsibility system needs further examination.) In addition, the subject of responsibility moves from the team to the individual at the lowest level, and the peasant's planning initiative and individual incentives are more 
heavily relied upon. But there is the risk of weakening the collective unit and neglecting collective undertakings, including water conservancy and public welfare. In extreme cases, there is the danger of simply dividing the land and collectively owned machinery and tools among the households. These problems are noted in the press. Measures have been undertaken to solve them, as in the case of the system used in Henan.

There remains one version of the responsibility system which cuts across the logical scheme described above, since it involves specialized work that is available for assignment to any of the three levels mentioned above, utilizing a contract system involving rewards and penalties. This system is known as zhuanye chengbao, lianchan jichou (contract work for specialized tasks, calculating reward by linking it to yield). Under this system, special tasks in farming, forestry, animal tending and husbandry, fishery sideline production, and industry and commerce that require specialized skills are assigned to a special work group, a household, or an individual. Thus, work groups, households, and individual farm workers specializing in one task frequently coexist within a team. A contract is concluded between them and the team with provisions for bonuses for exceeding the contractual obligations and penalties for failure to meet them. A simple example of this system is the assignment of milk production by several cows to a household. In more economically developed areas, there is a tendency for teams to make the transition from using the system of contract work for a small number of related tasks to the system of zhuanye chengbao, lianchan jichou (Renmin ribao, March 2, 1981: 1). ${ }^{23}$ A specialized task is assigned or a contract is awarded to a group, household, or an individual by two different methods. One is self-nomination and public discussion, the other competitive bidding. Recently, the merits of the second method have been stressed in the press.

The document on the responsibility system issued in September 1980 gave zhuanye chengbao, lianchan jichou high praise and compared it favorably with other forms of production contract system on the following grounds: It satisfies the commune member's demand for linking reward to yield; it stabilizes the primary economic position of the team; it integrates in concrete 
terms the promotion of the individual commune member's activism in production with the development of the superior characteristics of unified management, division of labor, and cooperation; it facilitates the development of a diversified economy, the extension of scientific farming, and the promotion of commodity production; and it eases the task of the members in taking care of sideline occupations (Banyue tan, April 25, 1981: 7). This form may be used in economically distressed areas and then developed into a more socialized division of labor among specialized tasks as the forces of production grow and the number of products increases (Banyue tan, April 25, 1981: 7; Zhan Wu and Wang Guichen, 1981: 55-59, 73).

In such work as basic farmland construction and water conservancy projects, a system of individual remuneration sometimes considered marginal to the responsibility system is still frequently used. This is the system of pinggong jifen. Sometimes, even difen huoping is used. There are attempts to use the ding e system in this kind of work. But the systems of difen siji and "selfassessment and public discussion" (zibao gongyi) are vigorously attacked as contributing to low labor productivity and difficulties in labor management.

The logical scheme we use also reveals roughly the progression of the responsibility system as it gained the approval of the Party Center and was promoted in the countryside. This trend was described by the officials of the Agricultural Commission of Henan province in terms of "eight breakthroughs" or, to be more precise, eight transformations: (1) from the absence of linkage between reward and yield to the establishment of this linkage; (2) from linkage between reward and yield for work groups to linkage for individual farm workers or households; (3) from linkage between reward and yield in the production of industrial crops to grain production; (4) from linkage between reward and yield in growing autumn grain crops to growing summer grain crops; (5) from linkage between reward and yield in agriculture to linkage in forestry, animal husbandry, sideline occupations, fishery, and so on; (6) from proportionate bonuses and penalties to full bonuses and full penalties; (7) from the adoption of the system by ordinary communes, brigades, and teams to adoption 
by those with a higher level of production; and, finally, (8) from fixing the production targets for one year to several years without change (Renmin ribao, July 2, 1981: 5). But despite this general trend, the main point emphasized is still that a team should adopt a form most suitable to its economic conditions and capability for management.

From our point of view, the seventh "breakthrough" is of utmost significance. It reveals to us how complete is the reversal of the Maoist agricultural policies adopted during the Cultural Revolution. It reflects the reformers' view that the responsibility system can achieve better results even in localities where the implementation of Maoist policies had increased production and improved the peasants' livelihood. This seventh "breakthrough" is forcefully illustrated by a brigade in Sichuan, well known for the strength of its collective economy. Until the end of 1980, all farming activities as well as industrial and sideline production had been under the direct, unified management of the brigade. For farming, the brigade had not been divided into teams or work groups, and no strict system of responsibility had been used. Still the per capita income distributed by the brigade to its members had reached $¥ 318$ in 1980 , as compared with the national average of Y85.9. Seventy percent of its total income came from the profits of industrial and sideline enterprises, which had been highly developed. But according to reports, the high profits covered up the inefficiency in the use of labor not only in farming activities but also in industrial and sideline production. After the autumn harvest, the brigade adopted the system of zhuanye chengbao, lianchan jichou. It assigned two-thirds of its members to fixed, specific posts in its 14 industrial and sideline enterprises. It gave each of its enterprises, their small groups or their individual workers a planned target of output value. The work points earned by each worker were decided on the basis of output value and the cost of the product with bonuses for surpassing the target and penalties for failing to meet it. For field management of farm work, it divided the remaining one-third of its members into seven fixed work groups. As a result, the harvesting of wheat and other produce in spring was allegedly accomplished in half a month without the customary help of 80 to 90 persons hired from 
other places. In the first four months, the net income of the industrial and sideline enterprises increased more than $56 \%$ (Renmin ribao, July 3, 1981: 2).

Several other new developments deserve to be mentioned briefly. In some places where baochan daohu was practiced, three to more than ten households voluntarily joined together to purchase farm machinery, to undertake irrigation projects, or to set up small work shops to process farm products. In a small number of cases, several households joined a brigade or team to form an economic enterprise, to which each individual would contribute an equal amount of money as his or her share and the brigade or team would put up the collectively owned land. These enterprises amass their own capital, produce and sell their own products, bear the responsibility for their own profits and losses, select their own personnel, and adopt their own management systems (Renmin ribao, July 17, 1981: 4, April 28, 1981: 1, March 21, 1981: 2, March 18, 1981: 1).

The system of responsibility has been extended to the cadres as an experiment. In one county in Ningxia, the Party committee signed contracts with cadres in the communes, brigades, and teams to specify their personal responsibilities with provisions for bonuses and penalties. For example, a contract concluded between the county and a commune used as the base line the averages of total grain production, total amount of grain sold to the state, and income from industrial and sideline production in the past three years. If the commune increased total grain production and grain sold by 10,000 catties or its income from industrial and sideline production by $¥ 10,000$, the county would give the cadres of the commune a bonus of a specified amount. If there was a decrease by 10,000 catties or $¥ 10,000$, the county would deduct from the salaries of the commune cadres a specified amount as penalties. This system was used in 1980 in all 71 brigades and their 564 teams in that county. In settling the account for that year, the cadres in 30 teams received penalties, while those in all other teams were given bonuses of varying amounts (Renmin ribao, February 17, 1981).24 In Guangdong, an association of scientific workers and its local affiliates signed contracts with three backward teams to popularize an improved method of 
farming. Under the contract, $5 \%$ of the increase would belong to the team. Everything above $5 \%$ would be divided equally between the two contract parties. Ten percent of the receipts of the association and its local affiliates would be used as bonuses for agricultural technicians who were stationed in these teams. If there was a decrease in production not due to natural disaster, the association would compensate the teams for their losses (Renmin ribao, April 12, 1981: 2). In the suburban area of Beijing, 240 contracts between scientific units on the one hand and commune or peasant households on the other were signed in the first seven months of 1981 (Dagong bao, August 4, 1981: 1).

The numerous forms of the responsibility system must have been bewildering even to the cadres and the peasants of China, not to say outside observers. In January 1981, Chinese leaders begun to sum up, simplify, and systematize their views on the responsibility system. In this summation, two trends in the development of the responsibility system are discernible, aside from those mentioned above. The most important is that increasing stress has been placed on three principal forms of the system of responsibility system with reward-yield linkage: (1) baochan daohu (household responsibility system) and da baogan (household total responsibility system), (2) tongyi jingying, lianchan daolao (unified management [combined with] linkage of the individual worker's reward to yield), and (3) zhuanye chengbao, lianxi chanliang jichou (contract work, for specialized tasks [combined with] calculation of rewards by linking them to yields). These three forms are said to fit respectively three different types of localities: (1) economically backward and hard-pressed areas, (2) areas at the middle range of economic conditions, and (3) areas where economic conditions are good and the collective economy is relatively strong. The second trend is that increasing efforts are being made to preserve the collective economy when the first and second forms are used. Even under the household total responsibility system, the production team must-it was stressed in one case-undertake unified planning for cultivation, unified plowing and sowing, and unified irrigating. When the system of linking the individual worker's reward to yield is used, it is specified that the systems of collective ownership, of unified 
distribution, and of using the team or brigade as the basic accounting unit should not be changed, and that planning for cultivation, plowing, use and control of water, and the care and use of draft animals and agricultural machinery and implements of large and medium sizes should be undertaken under the unified auspice of the team or brigade. 25

Our classificatory scheme, the cases used as illustrations, and our discussion of the trends and processes are all based on official reports which undoubtedly try to justify the responsibility system in terms of the demands, interests, and practices of the masses. At this moment we are not in a position to determine how correctly and accurately these reports reflect the real situation. But given our knowledge of the traditional practices of the peasants and the measures adopted during the three years of agricultural crisis, these reports cannot be totally misleading and deceptive. At the very least, they represent the views of the reforms and the policies of those in charge of agriculture. A few years hence, we shall be in a better position to judge the credibility of these reports, the validity of these views, and the success or failure of these policies.

\section{ADOPTION OF THE SYSTEM OF RESPONSIBILITY IN XIYANG AND DAZHAI SINCE 1979}

As we suggested in the first section, the peasants and lowestlevel cadres, in response to the change in the political atmosphere at the national summit, played a visible role in spontaneously developing various forms of the responsibility system; and the adoption of that system as a national policy was the product of interaction of impulses from the top to the bottom and from the bottom to the top. In contrast, the adoption of the responsibility system in Xiyang and Dazhai accompanied the downgrading and then the termination by the Party Center of the movement to learn from Dazhai and to build Dazhai-type counties and the publication of a series of self-criticisms made by Party committees of the county, district, and province since July 1978. This was clearly the product of the change in national policy and the effort of officials at all levels in Xiyang to "keep in step with the Party"-an effort which was opposed by Chen Yonggui. Within a 
week after the Fourth Plenum, and even before the official publication of "Decision on Certain Problems Concerning the Acceleration of Agricultural Development," Renmin ribao reported on October 3 (1979: 2) that a series of nine decisions had been made by the Xiyang Party committee in meetings held since August, when it had applied the criterion for testing truth in examining the ultra-leftist errors committed in the movement to learn from Dazhai. For our purposes, the most important decision was that the whole country should rigorously adopt the system of management by fixed work quotas and that the system of dividing a production brigade or team into work groups, assigning responsibility for work to the latter, and calculating rewards by linking them to yield should also be implemented. Thus, belatedly and just before the Fourth Plenum was to adopt an even more liberal version of the draft of December 22, 1978 as the definitive statement of policy (Renmin ribao, October 3, 1979: 6-13), ${ }^{26}$ the Xiyang party committee fell into line. The Party branch of Dazhai indicated that it "would also implement the system of management by fixed quotas." But it did not mention adoption of the system of assigning responsibility for work to work groups and calculating rewards by linking them to yield.

In 1979, all the brigades in Xiyang used a system of fixed quotas for at least part of their farm work, locally called ding $e$ baogong. For the autumn harvest, the deputy leader of the Dazhai brigade, Jia Changsuo, allegedly with the support of the cadres and members there, took charge in experimenting with the system of ding e baogong, which the Foreign Broadcast Information Service (April 14, 1981: R4) called "contract work" and the Dagong bao (May 8, 1981: 1) called baogong shengchan zeren zhi. As a result, the peasants of Dazhai spent ten days less than in former years to complete the harvest. Moreover, Dazhai was able to dispense with the help which had been given in the past by employees from the county seat (Interview in Dazhai, August 1980). When Chen Yonggui returned from Beijing, he dismissed Jia. But Chen himself was in turn dismissed as the secretary of the Xiyang Party committee in December and replaced by Liu Shugang, who for many years had been a deputy 
secretary in charge of industry. Li Xishen, the deputy secretary who had taken overall charge of running the county in the absence of Chen from Xiyang, was assigned only the task of handling finance and trade (Interview in Xiyang, August 1980). He was dismissed as a deputy secretary in the spring of 1980 . In late June, Guo Fenglian, secretary of the Dazhai Party branch, was transferred to work at the county seat as a cadre of twentythird grade at a monthly salary of $¥ 47.5$, with her specific job assignment to be determined at a later date. The Party committee of the Jinzhong district, which has jurisdiction over Xiyang, was also reorganized. Chen himself was to resign from his position as a vice-premier in September.

At the time of Tsou's visit to Xiyang county in August 1980, there were 419 brigades, four more than in 1979 and eight more than in 1976. With a few exceptions, all the brigades are divided into several teams which are roughly equivalent in function to the work groups described in the above scheme for the whole nation. With few exceptions, the brigades, not the teams, remain the basic accounting units. As Mr. Liu said, the brigades in Xiyang are relatively small, and the primary problem is implementing the system of production responsibility. Hence, at that time the county did not plan to make the team the basic unit of account. For large brigades, the teams are further divided into work groups. Of the 419 brigades, 247 brigades (59\%) adopted in 1980 the system of siding yijiang, under which each brigade assigns to its teams a fixed amount of land and labor on the one hand and a fixed target of yields in both quantity and quality and a target of investment or cost on the other, with provision for a bonus of $40 \%, 60 \%, 70 \%$, or $80 \%$ of above-quota yields and a penalty of $40 \%, 30 \%$, or $20 \%$ of shortfalls. Thirty-five brigades $(8 \%)$ have adopted the system under which all above target yields will belong to their teams or work groups. This system is the same as the third subtype of baochan daozu in our scheme of classification, although in Xiyang this mainly takes the form of baochan daodui (team). But in the interviews, the cadres called this system da baogan, an unavoidable confusion due to the lack of a standard terminology used uniformly throughout China. Twenty-four 
percent (101) of the brigades have adopted a system of linking the yields of the teams to the work points given by the brigade to the teams. For example, a team will be given ten work points for producing a certain amount of grain. Thirty-six brigades (9\%) have adopted a system under which the team will hand over to the brigade a fixed amount of its profits, its share of public welfare funds, its share of grain reserves, and a certain amount of grain for special use by the brigade. After having discharged these duties, the team keeps all its produce. ${ }^{27}$ This system is called elsewhere and in our classification da baogan daozu or, in the case of Xiyang, should be called da baogan daodui. In giving Tsou these figures, the local officials used the brigades as units. The meaning of these figures is ambiguous. It may mean that in a certain brigade under one of the four categories, all the teams maintain the stipulated relationship with the brigade. Or it may mean that only a majority or plurality of the teams do so.

The various brigades also have specialized work groups and specialized households for such tasks as forestry, coal mining, and raising oxen. The county authorities hope that in a few years $30 \%$ of the rural population will become members of specialized households or specialized work groups. They also plan to open up the mountain slopes to the peasants, to give each peasant a number of $\mathrm{mu}$, and to allow him or her to keep whatever can be produced.

The division of the brigade into teams began in 1979 after the draft document adopted by the Third Plenum in December 1978 had been sent down. Of the eight brigades visited in 1980, seven were divided into production teams and used the system of siding yijiang, which was conceded by the cadres to be essentially the same as the once-condemned system of sanbao yijiang. Dazhai did not adopt the system until early 1980 . The eighth brigade, Gaojialing, was a small village with 306 persons and served also as the site of the experimental farm for Dazhai commune. It was not divided into teams even in 1980 , nor were four other small brigades in Dazhai commune.

Interviews with the leading cadres in all three other communes visited-Gaoluo, Sandu, and Lijiazhuang—suggest that a major- 
ity of the brigades there have been divided into teams and used the system of siding yijiang in their relations with the teams. For the purpose of illustration, let us give a more detailed account of three brigades-Wujiaping, Qingyendi (in Gaoluo commune), and Dazhai-which are different from each other in some respects. Wujiaping is a large brigade with a population of 1,315 . In 1979, the brigade decided to set up seven specialized work groups totalling 77 persons for coal mining, forestry, brick making, manufacturing explosives, operating tractors and other machinery, raising vegetables, and raising pigs. The rest of the population was grouped into four production teams for farming, each with approximately 300 persons including more than 40 male and female full-time and part-time workers. Teams were further subdivided into work groups with about 15 farm workers each. In describing the relationship between the brigade and the four teams, the leading cadres in Wujiaping openly called it by its old name, sanbao yijiang (three guarantees and one bonus-that is, a labor-production-cost contract with rewards and penalties) and $s i$ guding ("four fixed specifications"-that is, fixed quantities of land, labor, draft animals, and farm tools assigned by the brigade for use of the teams) (Interview in Xiyang, August 1980). If a team obtains a yield above the agreed target of production, $40 \%$ of the above-quota yield will be retained by the team and $60 \%$ will be handed over to the brigade. This stands in contrast to the system used from 1966 to 1978 under which all produce had to be given to the brigade for unified distribution. The team assigns work quotas to the work group and a specific number of work points for their fulfillment. There is no provision for bonuses or penalties. In turn, the work group assigns work quotas with attached work points to the individual peasants. For some agricultural work, such as farmland construction, to which this method is difficult to apply, the system of awarding work points after appraising work performance is used instead of the system of work quotas. This appraisal is not done by self-assessment and public discussion, and political consciousness is no longer taken into account. It takes place within the team, not the brigade, in a meeting attended by team members. 
At the end of 1979, the workday value for the whole Wujiaping brigade before awarding bonuses and imposing penalties was set at $¥ 1.60$. Table 1 shows how the system of bonuses and penalties worked. It shows that all of the bonus was distributed to the farm workers through increases in the workday value. (For example, in the second team the $¥ 760$ bonus divided by 15,030 workdays comes to almost exactly $¥ .05$, which added to the base workday value for the brigade of $¥ 1.60$, results in the team’s workday value of $¥ 1.65$.) Despite this direct connection between bonus and remuneration, the system of fixed targets with bonuses and penalties does not seem to have provided a significant new incentive for greater effort in production. Total grain production in Wujiaping increased $6.4 \%$ in 1979 over 1978, but this is largely attributable to very good weather and to the fact that 1978 was not a particularly good year (itself only $2.4 \%$ over 1977 ). The brigade's base workday value of Y 1.60 in 1979 was only $14 \%$ above the 1978 figure of $¥ 1.40$, despite the fact that the state procurement price for grain had risen by $20 \%$ in 1979. The inequality among the teams in distributed income (as measured by the workday value) occasioned by the new responsibility system was marginal, though it may have stood as a warning for the future to teams which do not raise production commensurate with other teams. The evidence suggests, in short, that either because of its novelty or its specific features (or some combination of both), the system of fixed work targets with bonuses and penalties did not do much to spur incentives and production in its first year of operation in Wujiaping brigade.

Thus, the cadres of the brigade were considering two alternatives for 1981. The first was to replace the present system with the system locally called da baogan, under which all above-target yields would be retained by the team. This would be a rather drastic measure for Wujiaping. The second was to apply the present system to regulate the relationship between the work groups and the team. As the work group was one-third the size of the team, the linkage between the efforts of the individual peasants and their rewards would be more visible to the peasants. 


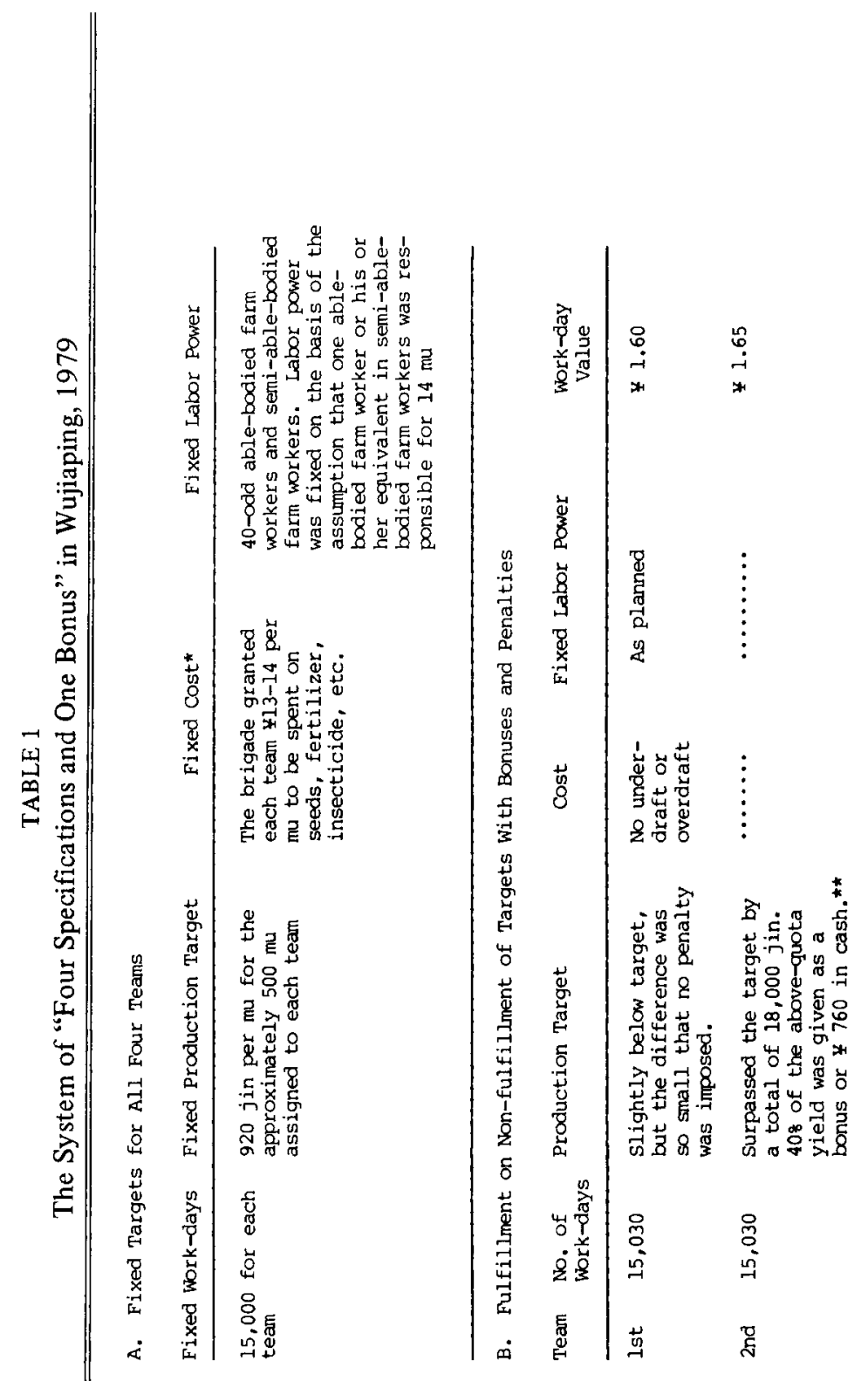




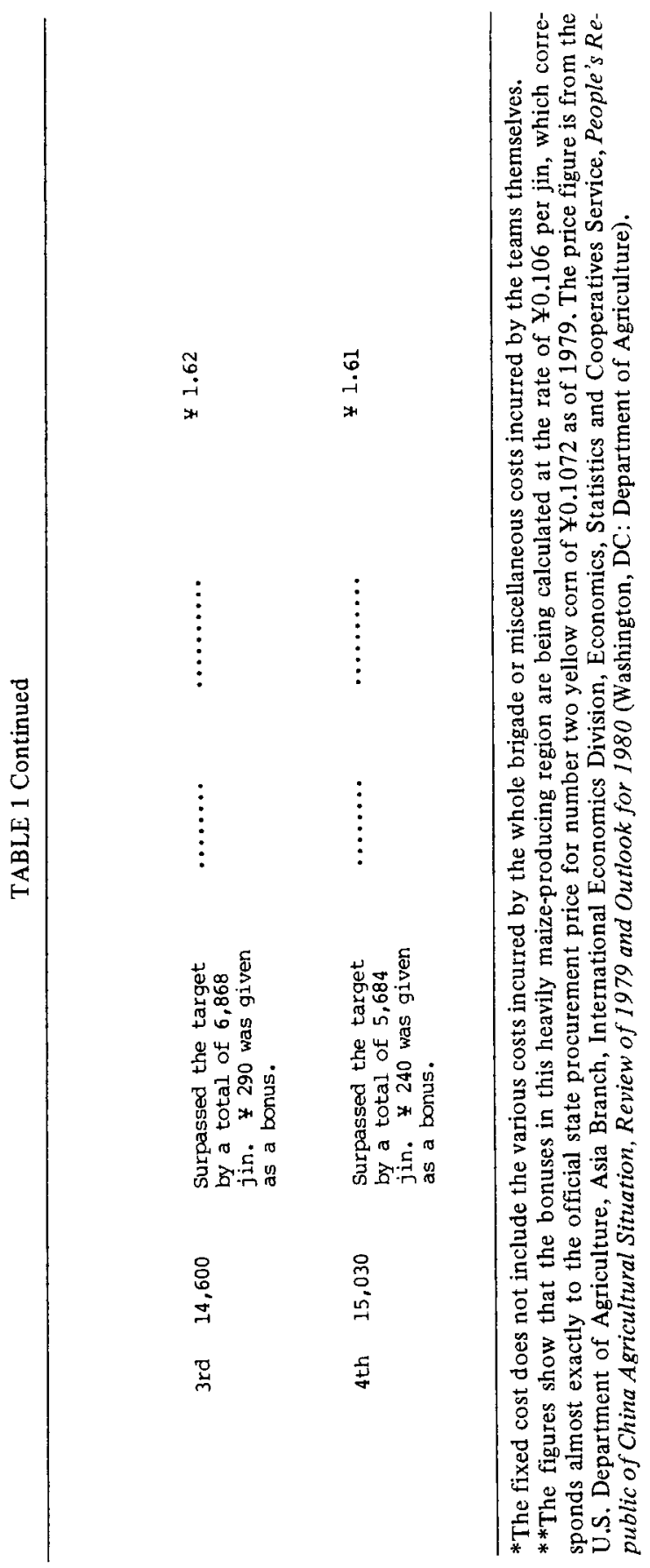


In other words, the guiding idea that the peasants must be given greater material incentives would be pushed one step further.

The second case was cited by top county officials as a sterling example of their success in implementing the new system and of the virtue of making the units in the responsibility system as small as possible without destroying the brigade as an accounting unit. Qingyendi brigade in Gaoluo commune had a population of 530 in 1980, which was slightly larger than that of Dazhai (which had a population of 470 ). But it had 1,374 mu of cultivated land, while Dazhai had only $846 \mathrm{mu}$. In 1979, the system of siding yijiang was implemented to govern the relationship between the brigade and the two teams plus one work group into which the brigade was divided. The work group consisted of only five households with 28 persons, five male farm workers, and four female farm workers. The members of all the households are kin and share the surname of Zhu. The male heads of three of the five households are brothers. All five households live close together in a small hollow some distance from the highway. This natural unit, known traditionally as Zhujiazhuang, is surrounded by $137 \mathrm{mu}$ of terraced fields, which are separated by topographic features from the fields cultivated by other teams. These $137 \mathrm{mu}$ of land were assigned by the brigade to be cultivated by these five households. Thus the cultivated land per person amounted to $4.9 \mathrm{mu}$, in comparison with the average of $2.4 \mathrm{mu}$ per person for the other two teams. In 1979, Zhujiazhuang obtained a yield of 103,483 jin of grain in comparison with 70,000 jin in 1978 (a year of bad weather) and 90,000 jin in 1975.

Table 2 summarizes the 1979 targets and final outcome of the "four specifications" in Zhujiazhuang. On the basis of these figures, Zhujiazhuang was to receive a bonus, but in a two-step fashion, the first based on a preliminary estimated income of $¥ 9487.10$, which surpassed the income target of $¥ 8,207.00$ by $Y 1,280.10$. This surplus of $Y 1,280.10$ was added to the value of saved labor of $¥ 849.80$, from which the cost overrun of $¥ 465.60$ was subtracted, producing a net surplus of $¥ 1,664.30$. Under the responsibility system adopted there, Zhujiazhuang was entitled to 


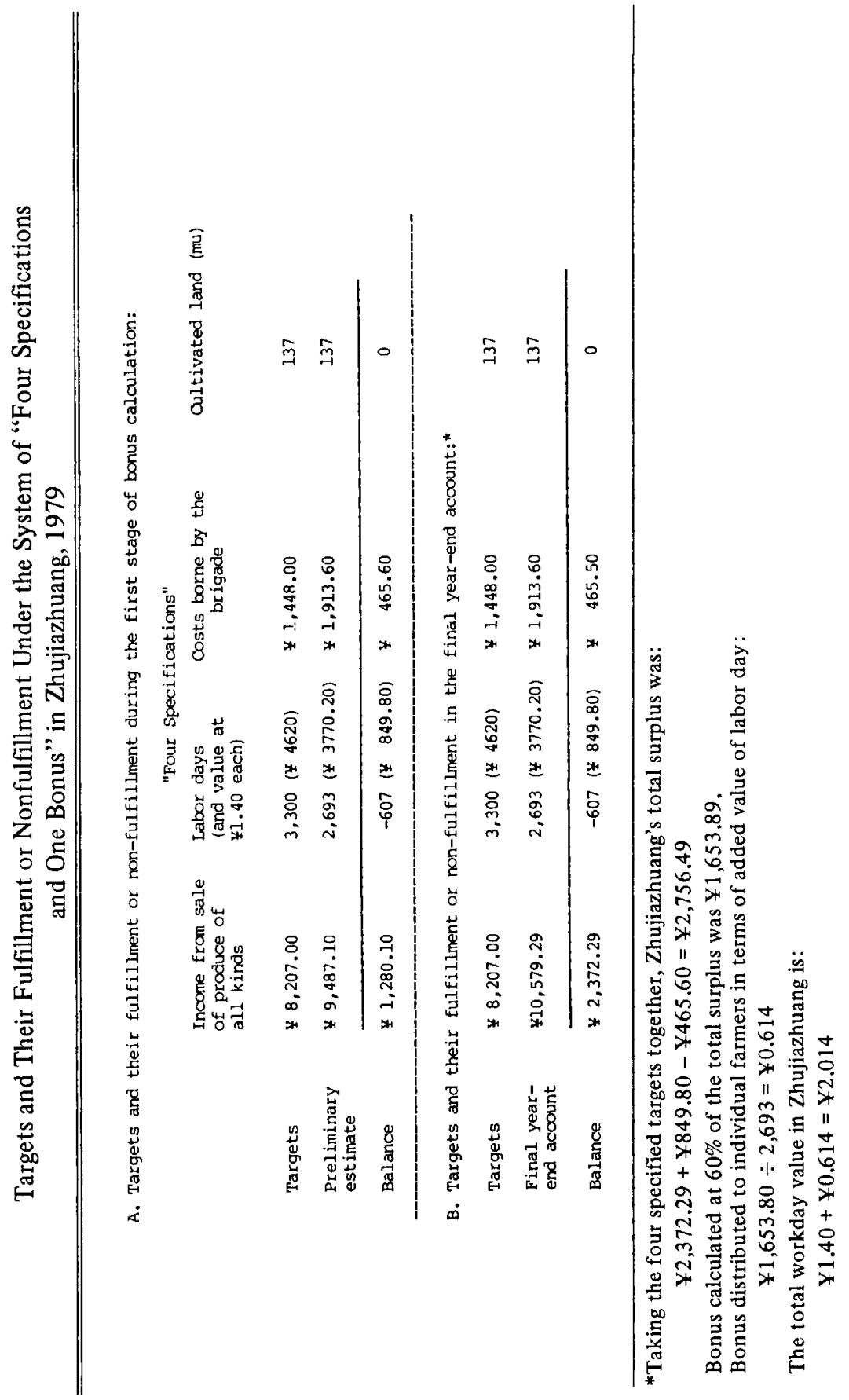


receive $60 \%$ of this, or $¥ 998.58$, as a bonus; this figure in turn amounted to $¥ .371$ for each of the 2,693 labor days put in by the peasants in Zhujiazhuang. This pushed the workday value from the brigade base of $¥ 1.40$ to $¥ 1.771$. The second stage of the bonus calculation began from the fact that Zhujiazhuang's actual income for 1979 turned out to be $¥ 10,579.29$, which was $¥ 1,092.19$ in excess of the preliminary estimate of $¥ 9,487.10$. Of this extra surplus, $60 \%$ was $¥ 655.31$, which added another $¥ .243$ to the value of each of the 2,693 labor days, bringing the total workday value to $Y 2.014$. (For reasons which remain unclear to us, but which probably have to do with the delay in the calculation of the actual gross income figure, the $Y .243$ had not yet been distributed at the time Zhujiazhuang was visited: this amount was still due from the brigade.) In contrast, the final bonuses for the first and second teams of the brigade were $¥ .01$ and $Y .02$, respectively. County authorities had decided to reward further Zhujiazhuang's strong efforts by building a power line to supply it with electricity; the peasants there were talking about purchasing television sets.

Though we cannot answer it fully, we can now pose the question of the success of the new responsibility system (at least in terms of the stated goal of spurring production) in Zhujiazhuang compared with the other two teams in Qingyandi brigade as well as with Wujiaping brigade. The differences were probably related to the differences in settlement patterns, especially that Zhujiazhuang, an isolated grouping of only five households, is far smaller and more compact than the teams in the Qingyandi or Wujiaping brigades. One goal of the new policies on rural organization and management is to increase the directness of link between effort and reward by reducing the size of the collective units. Such smaller units are far better suited to the historical context and human-geographic environment of Zhujiazhuang. The contrast with Wujiaping may also have something to do with the relatively higher level of collective institutions, practices, and social relations there; Wujiaping was, after all, the first brigade in Xiyang to emulate Dazhai. 
At the end of 1979, Dazhai fell into line and proceeded to divide into production teams. According to one cadre in Dazhai, even Chen Yonggui agreed with the plan. In March 1980, the arrangement was completed. The brigade was divided into three teams with an equal number of farm workers of equal capacity for work on each team. All brigade members were first classified into groups according to the basic work points they had earned for each day of work in 1979, ranging from 5.5 to 10 work points. They were assigned to one of the three teams by lot. Three young peasants, aged 27,32 , and 37 , were selected among seven candidates as heads of the teams. One of the three had served as head of the agricultural science section for several years. He and another team leader are Party members, while the third is not. Meanwhile, the revolutionary committee had been reorganized into a management committee of 13 members. A young man in his 30s, who was a candidate for Party membership and who was therefore not a member of the Party branch, was selected as the head of the brigade, replacing Liang Bianliang, who as a 16-yearold boy had joined Chen's first mutual aid team in 1946 and who was now 50 years old and not in the best of health. But the Party branch had not been reorganized at the time.

The system of "four specifications and one bonus" (siding yijiang) was adopted to govern the relationship between the brigade and the teams. In addition, specialized work groups were set up under the direct supervision of the brigade to handle forestry, animal husbandry, vegetable gardens, and sideline production. Over 70 male and female farm workers were assigned to these specialized work groups; the remaining 120 farm workers were divided among the three production teams-a system which had been used at one time or another before 1960. Although the reestablishment of a system eliminated 20 years ago was the result of the decision to keep in step with the Party Center, several cadres in Dazhai-particularly those directly responsible for production-conceded that this revived system made labor management easier because of the reduction in the size of the management unit and the more obvious linkage between reward 
and the work done. A team is now managed by a team leader, a deputy team leader, and four work point recorders.

As for the method by which the team pays the peasants for work done, Dazhai cadres still find the system of payment by fixed work quotas (which had been abolished for all farm work in 1963) difficult to implement, although they have now readopted it for several kinds of farm work - for example, hoeing, applying fertilizer, and harvesting. But for a majority of farm work, the system of granting work points after appraising work performance continues to be used. The basic work points for a peasant were still to be decided once a year, but in a meeting of the members of the team rather than the brigade. In describing this system, the cadres gave the impression that it was essentially the system of "fixed [basic] work points [for a person] plus flexible appraisal [of work done]" (sifen huoping). But the system of self-assessment and public discussion using political consciousness as one of the four criteria for determining work points was definitely abandoned after it had been applied to all kinds of farm work for 17 years. Dazhai cadres recognized that they had to implement the principle of distributing income according to work done, as decreed by the Party Center. But they did see the negative implications of the new system of fixed work quotas and of appraising work performance. They noted that households without adequate labor power and old, sick, weak, and crippled peasants would be adversely affected, although they themselves would have a higher income at the end of the year. It is clear that the original system had enjoyed strong support among the peasants in Dazhai and that even those with physical strength and technical skills had internalized the attitude of looking at the interests of the village as a whole rather than considering their own self-interests exclusively. In contrast to Dazhai, all the other brigades and communes visited used the system of giving work points according to fixed work quotas in a majority of farm work. In Dongyetou and Lijiazhuang commune, it was applied to $80 \%$ of all farm work. In Sandu brigade, the system of giving work points after an appraisal of work done (pinggong jifen) was 
replaced completely by the system of giving work points according to fixed work quotas (ding e jigong) and another system which involved the use of work quotas plus bonuses and penalties.

ECONOMIC GROWTH AND EQUALITY

IN XIYANG SINCE 1976

What had happened in Xiyang county between 1976, the year in which the movement to build Dazhai-type counties was in full swing, and 1979, the first year in which the movement was in full retreat and many changes in institutions and practices took place? Tables 3 and 4, the raw data of which were supplied by county authorities in 1977 and 1980, give a schematic picture of the increase in workday values and the growth in income in all brigades. Lorenz curves constructed from these tables and presented here are intended to provide a visual image. Together, they also suggest some tantalizing questions about the problem of equality within the county.

Tables 3 and 4 show that the average of the workday values of all Xiyang brigades increased from $¥ 1.18$ in 1976 to $¥ 1.31$ in 1979 (an average annual rate of $3.5 \%$ ), while average collectively distributed income per capita increased from ¥ 105 to $¥ 125$ over the same period (an average annual rate of $6 \%$ ). But the weather in 1979 was unusually good. In 1979, the state increased the procurement prices by $20 \%$ for grain sold within the quotas set by the state and an additional $50 \%$ for above-quota grain. Moreover, the state set the quota for unified purchase for the whole nation at $5,000,000,000$ jin less than in 1978. In Dazhai, this policy lowered the quota for unified purchase from 160,000 jin to 120,000 jin, which had the effect of increasing the proportion of grain purchased at the higher above-quota price. Dazhai sold the state $600,000 \mathrm{jin}$, with 480,000 jin at above-quota prices. The county average of $¥ 131$ of per capita collectively distributed income is far above the national average of $Y 83.4$ (Renmin ribao, May 1, 1980: 4), the average for Sichuan of $Y 80.1$, and the average of $Y 96.1$ for the rural area of Sichuan's Leshan municipality also visited in 


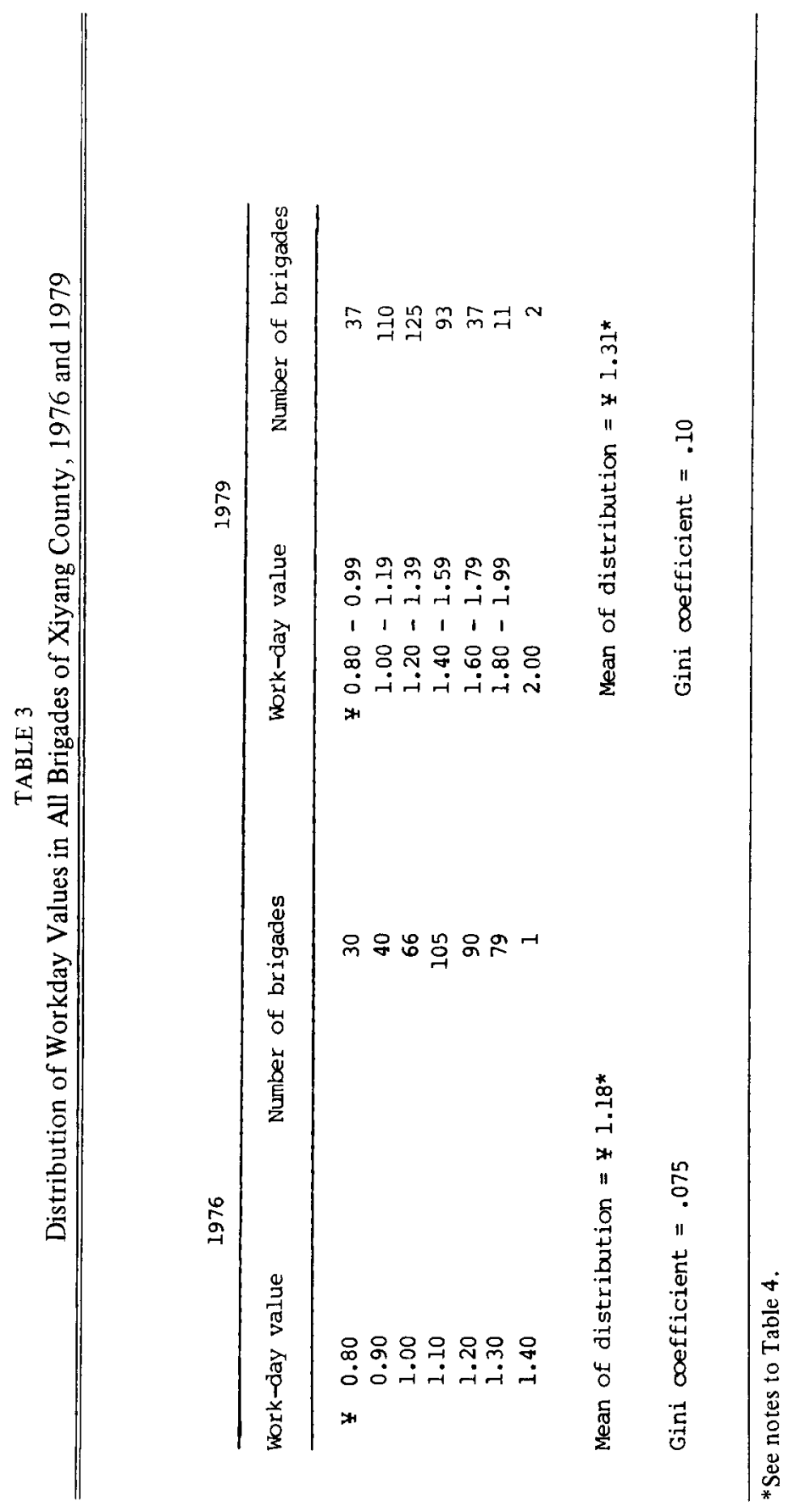




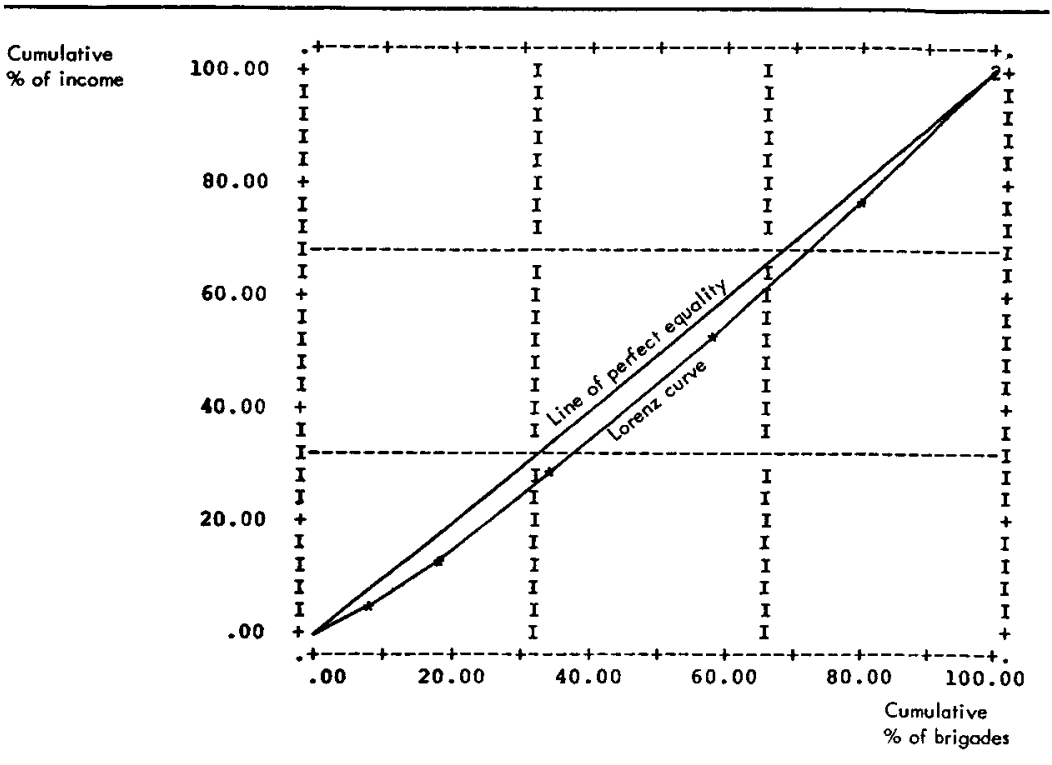

Figure 1: Lorenz Curve of Category Distribution of Workday Values in All Brigades of Xiyang County, 1976

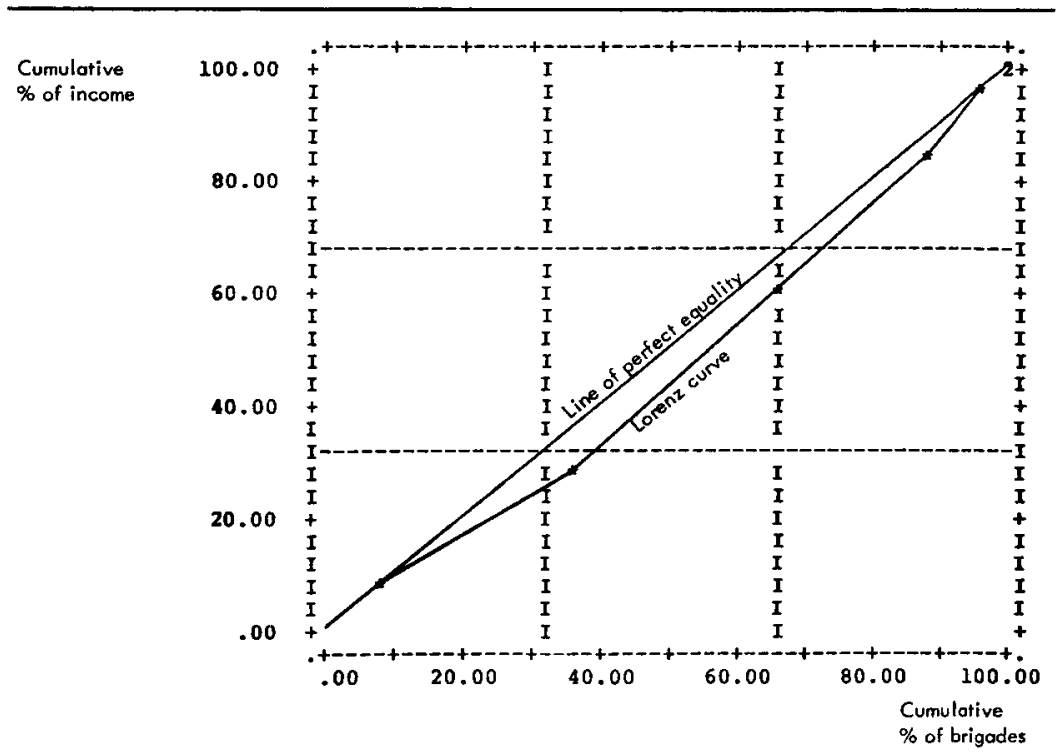

Figure 2: Lorenz Curve of Category Distribution of Workday Values in All Brigades of Xiyang County, 1979 
TABLE 4

Distribution of Average Annual Per Capita Collectively Distributed Income in All Brigades in Xiyang County, 1976 and 1979

\begin{tabular}{|c|c|c|c|}
\hline \multicolumn{2}{|l|}{1976} & \multicolumn{2}{|c|}{1979} \\
\hline $\begin{array}{l}\text { Average Annual Per-capita } \\
\text { Collectively Distributed } \\
\text { Income }\end{array}$ & $\begin{array}{l}\text { Number of } \\
\text { Brigades }\end{array}$ & $\begin{array}{c}\text { Average Annual Per-capita } \\
\text { Collectively Distributed } \\
\text { Income }\end{array}$ & $\begin{array}{l}\text { Number of } \\
\text { Brigades }\end{array}$ \\
\hline$* 40-49$ & 1 & $¥ 70-79$ & 15 \\
\hline $50-79$ & 50 & $80-99$ & 55 \\
\hline $80-99$ & 151 & $100-119$ & 101 \\
\hline $100-149$ & 207 & $120-139$ & 121 \\
\hline \multirow[t]{2}{*}{$>150^{\star}$} & 1 & $140-149$ & 47 \\
\hline & & $>150^{\star}$ & 76 \\
\hline \multicolumn{2}{|c|}{ Mean of distribution $=¥ 105^{\star}$} & \multicolumn{2}{|c|}{ Mean of distribution $=¥ 125^{\star}$} \\
\hline \multicolumn{2}{|l|}{ Gini oofficient $=.11$} & \multicolumn{2}{|l|}{ Gini coefficient $=.11$} \\
\hline
\end{tabular}

*In the absence of population data for the brigades, all calculations were made on an unweighted basis. The means on these tables were calculated from the distributions; hence they differ from the actual countywide means. The mean per capita collectively distributed income reported by county officials for 1976 was $¥ 94$, and in $1979 ¥ 131$. For the distributions in Table 4, "more than $¥ 150$ " was taken arbitrarily to be $¥ 160$. For the 1979 distribution in Table 3 and both in Table 4 , the midpoints of the income categories were used in calculation.

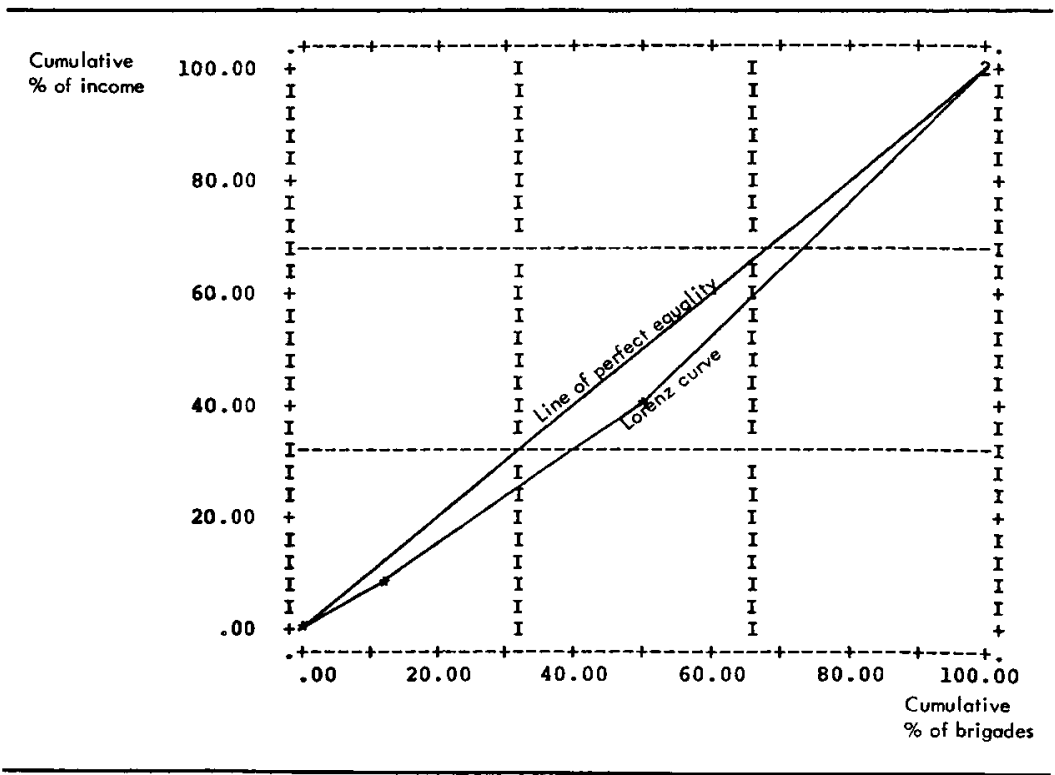

Figure 3: Lorenz Curve of Category Distribution of Average Annual Per Capita Collectively Distributed Income in All Brigades of Xiyang County, 1976 


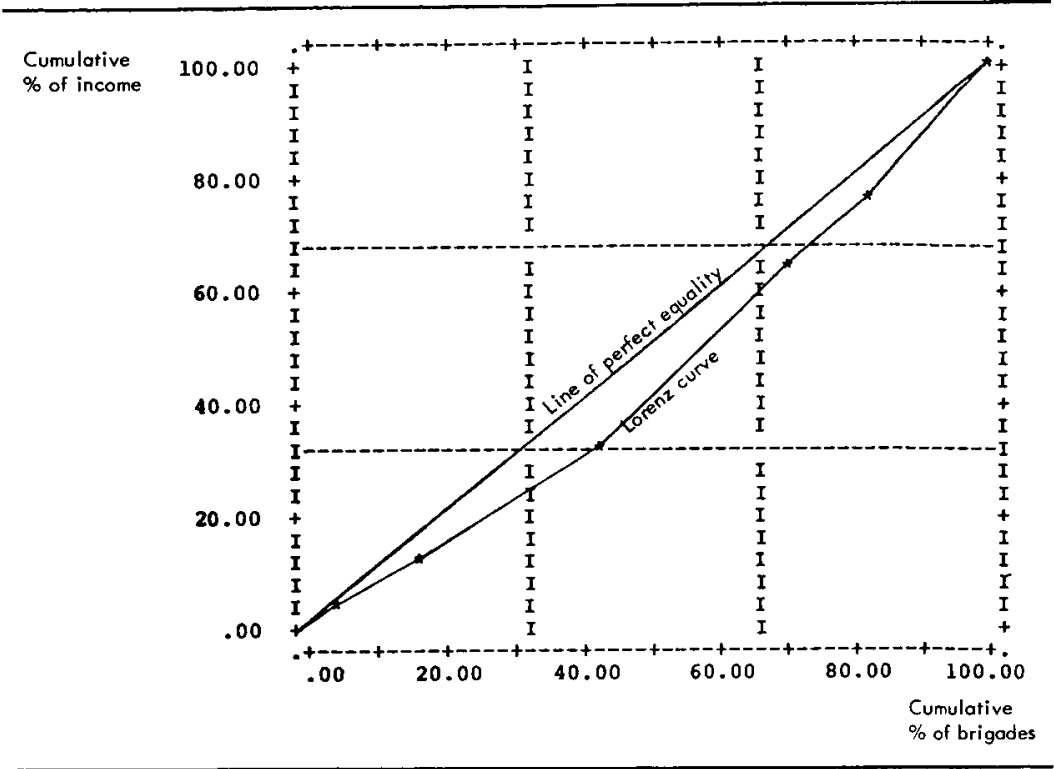

Figure 4: Lorenz Curve of Category Distribution of Average Annual Per Capita Collectively Distributed Income in All Brigades of Xiyang County, 1979

1980. But the peasants in Xiyang received only $¥ 9.3$ per capita ( $7.1 \%$ of the collective figure) from family sideline occupations. In comparison, a sample survey of 700 households in Sichuan shows that the per capita income from family sideline occupations in 1979 was $¥ 76.7,28$ while a nationwide sample survey of 10,282 households puts the per capita net income from household sideline occupations in 1979 at Y44.0 (Renmin ribao, January 3, 1981: 1). ${ }^{29}$ In any case, Xiyang suffered from a serious drought in 1980 , and agricultural production would probably decline. But the county authorities still hoped that the development of various kinds of brigade enterprises, a more diversified economy, and sideline production would keep the decline in the peasants' income to a minimum.

Tables 3 and 4 are difficult to interpret from the point of view of the effect on income distribution of the removal of the $¥ 1.30$ upper limit on the workday value which had been imposed on all brigades except Dazhai, the return of many small enterprises to the 
brigades, and the freedom given to brigades to develop new small enterprises. The Gini coefficients for the distributions of average annual collectively distributed income per capita show no change from 1976 to 1979 , while those for workday values rose from .075 to .10 , a change which is small in absolute terms but actually quite large in percentage terms. ${ }^{30}$ Although the data tend somewhat in the direction we would expect-toward indicating increased income inequality -it is probably premature to use them to judge the effects on income distribution among brigades of these policy changes (specifically, those relating to the brigade enterprises and the limit on distributed income) which had been in effect in an overwhelming majority of the brigades for only one of the years in our data series. We would expect the cumulative effects of these policies over at least their initial years to result in increased economic inequality among brigades. One dramatic example has already appeared. Shiping brigade, which recovered the responsibility for its coal mine from the commune level, was one of only two units in Xiyang to achieve a workday value of $¥ 2.00$ in 1979.

THE PARTY RENDERS ITS FINAL JUDGMENT ON DAZHAI, AND XIYANG LOOKS AHEAD

From December 9 to 13, 1980, the Party committee of Shanxi province held a meeting of Party representatives to elect the province's delegates to the prospective Twelfth Party Congress. To prepare a list of candidates, an enlarged meeting of the standing committee of the provincial Party committee was held in August and was followed by an enlarged meeting of standing committees of the Party committees of all the districts, cities, and counties. At both meetings, an overwhelming majority of those present refused to nominate Chen Yonggui as a candidate. In the meeting of the Party representatives in December, the Party leadership of the province explained to those assembled that to nominate Chen as a candidate for election would express the Party's consistent spirit of "learning from the past mistakes to avoid future ones." It also noted that recently he had understood his mistake and made a self-examination. Apparently, he was 
nominated as a candidate but failed to be elected (Tian Beizhi, 1981: 20-21).

In the same month, an election of a new Party committee of the Dazhai Party branch took place, using the new system of secret ballots with more candidates than the number of persons to be elected. The nine candidates had been selected earlier by a general meeting of the Party branch from names suggested by individual Party members. Chen had been nominated as one of the nine candidates, but he lost in the final election. Jia Changsuo, who had been dismissed by Chen in 1979 but rehabilitated in 1980 and had been nominated unanimously, was elected the new secretary (Zhang Jinxing and Jin Jiasheng, 1981: 21-22). The new Party committee of seven now consists of four new members and three former members. The reason given for Chen's failure to be elected was that he had not made a self-criticism to the people at Dazhai (FBIS, April 16, 1981: R4).

On February 12, Renmin ribao made public the final judgment of the Party on Dazhai and the movement to learn from Dazhai in Shanxi and throughout the nation, which took the form of a commentary on the self-criticism of the provincial Party committee of Shanxi. ${ }^{31}$ The Party Center affirmed that prior to the Cultural Revolution Dazhai had indeed been an advanced model on the agricultural front. But it stressed the point that since the beginning of the Cultural Revolution, it had become the model of implementing the "leftist line" and that the movement to learn from Dazhai had brought about serious consequences. The selfcriticism of the provincial Party committee specifically defined this "leftist line" of Dazhai and Xiyang as "so-called firmly upholding the continued revolution under the dictatorship of the proletariat." For our purposes the most relevant points made in the attack on Dazhai are: (1) Models should not be established artificially or maintained through deceptive methods. (2) Many different kinds of models should be discovered and cultivated in the light of the variations in China's countryside. (3) Any advanced technique and managerial method must be linked to 
the economic interests of the local peasants, must produce economic results, and must be accepted voluntarily by them.

Meanwhile, from August 1980 onward, the Xiyang county authorities had been trying to push forward the adoption and refinement of the responsibility system. Initially, they had recognized the defects of the system of "four specifications and one bonus" in its present form. Some teams had 80 households. They were regarded as still too large. They could, the officials thought, be reduced in size by half and further be divided into work groups of about ten households each. Within the work group, several households could sign a production contract and retain all produce above the quota stipulated in the contract. The guiding idea was that the more specific and concrete the system of responsibility, the better. Officials pointed to Zhujiazhuang work group as an example of success in applying this principle. They were pushing for the system under which all above-target yields would belong to a team or work group. In the distribution of rewards by the team to individual farm workers, the defect in the system of giving work points according to fixed quotas of encouraging the neglect of quality of work was recognized. The cadres were planning to replace it gradually with the system of lianxi chanliang jichou. But the officials stopped short of advocating the system of contract work by individual households (baochan daohu) which is being used in $20 \%$ of the teams in the nation and is practiced by $40 \%$ of the households in one subdistrict in a rural area of Luoshan city in Sichuan (Interview in August 1980) and more than 70\% of the teams in Funan county in Anhui (Renmin ribao, January 23, 1981: 2). This contrast between the policies of Xiyang county and Luoshan city in Sichuan reflects their respective residential patterns. Except in mountainous areas like Mengshan brigade or some places in Xizhai, the peasants in Xiyang have traditionally lived in village settlements. The movement to build new villages after the fashion of Dazhai has made the villages even more tightly knit than before. In Sichuan, the houses of peasants are more scattered. In 
hilly areas, single households or tiny groupings of two or three households may exist at quite a distance from each other and from other settlements. The contrast between Xiyang and Funan arises from the utter poverty and backwardness of Funan and its inadequate leadership and management system.

In spite of all these changes, county officials were still trying to strengthen the brigades by supporting the development of brigade enterprises and sideline occupations. They were still underscoring the indispensable function of the brigades and communes in water conservancy, irrigation work, small industrial enterprises, sideline production, and other undertakings which cannot be initiated and managed by the teams.

County officials realistically acknowledged that grain production in Xiyang would soon reach an upper limit even if the changes in institutions and practices brought about desirable results. They would be satisfied if they could achieve an annual grain production of $280,000,000$ jin to $300,000,000$ jin and keep it at that level. ${ }^{32}$ Meanwhile, they planned to diversify Xiyang's economy, reduce the amount of land devoted to grain in order to develop forestry and animal husbandry, and change the composition of grain produced by increasing wheat and soybean cultivation and cutting down on maize. Above all, they wanted to give the peasants time to rest and recuperate from too many demands and restrictions imposed by cadres of the brigade, the commune, and the county. They hoped that by allowing them greater freedom of choice and by providing greater economic incentives, the peasants would become rich through individual effort or by the common endeavor of close-knit units much smaller than the current brigades or even teams.

Since then, plans of the county authorities as well as their endeavor to keep in step with the Party Center have resulted in further changes. A dispatch from Taiyuan published on April 15, 1981 suggested that by this time, $86.8 \%$ of the production teams in Xiyang had adopted one or another form of the system of responsibility. Of these, $35 \%$ had adopted the system of dividing a team into work groups and linking the incomes of the groups to their yields, although the brigade remains the basic unit of 
account. Thirty-eight percent had adopted the system of linking the incomes of the teams to their yields. Two percent had adopted the system of linking the reward for an individual farmer to yield. One hundred ninety-two households living in remote hilly areas had adopted the "household responsibility system" (baochan daohu). ${ }^{33}$ Initial steps had been taken to implement the system of "contract work for specialized tasks." More important politically is the high praise that the commentator of Renmin ribao (April 15, 1981: 1) paid to Xiyang county under the leadership of its new Party committee in breaking the leftist ideological and political fetters of the past and in achieving another "liberation." The new Party committee was credited for drawing a line between the errors committed by "individual leaders" and the actions of the other cadres and the masses, thus protecting the activism of the latter and encouraging them to continue to work in the spirit of hard struggle. This transformation was held up as an example to other localities where the cadres were still "poisoned" by leftist ideas. Thus, Xiyang has redeemed itself in the eyes of the Party Center.

\section{CONTINUITY AND CHANGE: CENTRALIZED POLITICAL CONTROL, EGALITARIANISM, AND BUREAUCRACY}

Our survey suggests that the evolution of the responsibility system is the product of the endeavor of the Party authorities at all levels to adjust the system of collective economy as it has developed since 1956 to the immediate interests and spontaneous demands of the peasants. In so doing, they have revived and expanded some of the practices adopted during the three years of agricultural crisis and during the initial phase of the cooperativization movement in 1953-1955. They have also developed some new forms, such as lianchan daolao zeren zhi (also known as tongyi jingying, lianchan daolao) and zhuanye chengbao, lianchan jichou. This readjustment can be viewed from two different perspectives. In one respect, it represents an endeavor to solve the "free ride" problem and the crisis of motivation which had developed in the system of collective economy and was aggravated 
by the movement to learn from Dazhai. The value and limits of these institutional changes as measures to spur agricultural growth we shall leave to the future.

These recent reforms, together with the development of rural institutions and practices since 1953, can also be examined as a problem of continuity and change. We wish to suggest the following approach to this problem of historical interpretation. From this point of view, rural society in imperial China can be viewed as having been organized by two institutional arrangements: first, a top-to-bottom control by a centralized bureaucracy down to the level of the county; and second, a system of precapitalist "free enterprise" at the local level. As Philip Kuhn notes (1981: 1-17), the "gentry society" of the late imperial period lacked the support of effective concepts of immanence and representation. It "could generate little more than a pallid parochialism" in view of the immense power of the state and the weakness of a traditional local community autonomy in the sense of local areas generating a truly powerful stratum of indigenous leadership.

Under the post-1949 Chinese state, centralized political control not only penetrated downward to the grass roots but also extended horizontally to the economy and other aspects of social life. The total crisis which engulfed Chinese society and its relations with foreign powers in the first half of the twentieth century rendered the rebuilding of a strong, centralized state and bureaucratic system necessary, or at least made it seem acceptable to many Chinese. It predisposed some Chinese intellectuals to accept Marxism, which is a theory of total crisis. It legitimized the endeavor to make a social revolution which would destroy the traditional class structure; bring about a redistribution of income; reshape social institutions; industrialize the country and modernize its culture and change people's ideas, attitudes, and habits. A strongly centralized Party state with a planned economy commanding and centrally directing numerous collective economic units emerged. In the rural areas, the communes staffed by officials appointed from above and receiving salary from the state became both political and production units. The brigades and teams below them were penetrated by Party branches, Party 
small groups, or Party activists. The central places at the lowest level in the natural system increasingly assumed the character of administrative and political units performing tasks assigned from above. Bureaucratic control overwhelmed spontaneous economic activities.

During the Cultural Revolution, the fractionalization of the Leninist Party at the national summit, the initial destruction of the system of Party committees and governmental units below the Central Committee, and the decreased capability of the rebuilt Party and governmental organs did not weaken the centralizing impulse. Indeed, the impulse found even fuller expression in the leftist revolutionary ideological and political line initiated by Mao and carried to the extreme by the "Gang of Four" with the support of mobilized and aroused masses - at least for a time. The idea of the primacy of politics and the practice of organizational control and mass mobilization were pushed as far as humanly possible. The limited sphere of precapitalist free enterprise in both rural and urban areas which had survived up to this time shrank still further. It was attacked as a "spontaneous tendency toward capitalism" rather than regarded as a survival of precapitalist free enterprise which had developed over centuries. It was not considered a necessary supplement to the farming activities of the peasants in eking out a living under a collective economy in the countryside or to the socialist economy in the cities.

In the countryside, the movement to learn from Dazhai and to build Dazhai-type counties marked the culmination of this trend. The use of a single national model for developing agriculture and organizing rural life was a concrete expression of the centralizing impulse which had been inherent in the political organization of the Chinese Empire but was checked by the economic structure of precapitalist free enterprise at the local level, the technological backwardness of transportation and communications, and the size and diversity of China. Thus, the trend toward centralization, uniformity, and standardization in the performance of all functions and in a program to reshape socioeconomic institutions was pushed forward by a mass political movement led by an apotheosized supreme leader. At the national level, it encountered 
nothing more than ingenious attempts to prevent it from going to the extreme, endeavors to evade its full impact in the process of implementation, concealed opposition, and hidden dissent. At the local level, however, it met extensive evasion and passive resistance.

But the program to eliminate the remnants of precapitalist free enterprise through a mass political movement in a short time was bound to fail, and the endeavor to use one model ran directly counter to the wide variation in geographical conditions throughout the vast expanse of China, in the traditional pattern of village life, and in the capability of the political organization and leadership in numerous local units of production and governance. Hence, the movement to learn from Dazhai did not bring about the desired result in vast areas of China where conditions were very different from those in Dazhai. It stifled individual initiative. It did not enable the local units to cope with problems specific to them or with newly emergent problems in time. It hindered the effort to improve agricultural productivity and to raise the peasants' living standards.

In the national context of rejecting Mao's ideological and political line of the Cultural Revolution period, the repudiation of both the movement to learn from Dazhai and the post-1966 developments in Dazhai itself marked a reversal of the strong and accelerating trend toward centralization in twentieth-century China, a reversal of the tendency for politics in the form of mass political movements and bureaucratic control to penetrate to the lowest level of society for the purpose of restricting or eliminating what had remained of precapitalist free enterprise in the countryside. The reversal of this tendency and the rehabilitation of some types of precapitalist free enterprise are nowhere more obvious than in the encouragement of household sideline occupations, the protection and enlargement of private plots, and the revival of the rural markets. But the changes go much farther and deeper. The most fundamental change can be found in the promotion and perfection of the system of responsibility in agricultural production, which we have described in this article. The regime has now gone as far as it can in readopting some of the traditional forms of relations of production and farming practices short of a reversion of land and collectively owned means of production to private 
ownership. It attempts to effect a synthesis of the new institutions and practices adopted since the nationwide movement to organize cooperatives in 1955-1956 with some of the traditional institutions and practices of individual farming. To enable the production team to make these institutional changes in light of its specific circumstances, the idea of autonomy of the team has been underscored and propagated. The reversal of the trend toward increasing centralized political control also finds expression in the provinces, municipalities, and counties and the policy of devolving many more functions to them.

A similar approach can be applied to understand the drive toward egalitarianism in the countryside. It is common knowledge that in the revolutionary process the peasants constituted the major force. Egalitarianism in economic matters was a central feature in traditional peasant rebellions which have been considered by the Chinese Communists as the antecedents of their revolution in a different stage of historical development. To be sure, Mao and other Chinese Communist leaders drew a sharp distinction between "agrarian socialism" and "scientific socialism" or between "populism" and Marxism (for example see Gong Yuzhi, 1981a, 1981b). They rejected "absolute egalitarianism" or "extreme egalitarianism" which characterized the economic program of traditional peasant rebellions. But as the early pronouncements on the communization program, many developments in the Cultural Revolution culminating in the call for the restriction of "bourgeois right," and the movement to learn from Dazhai show, the search for a greater degree of economic equality was a major impetus to continued radical transformation in the countryside as well as its justification.

In their attempt to find the social basis for the Cultural Revolution and the leftist errors in policies since 1957, several Chinese intellectuals trace radical egalitarianism to China's "small producers," particularly the peasants. They call for a new effort to eliminate "peasant ideology" (Wang Xiaoqiang, 1980; Luo Hanxian, 1980). That this line of analysis may have serious and harmful political and social consequences has been noted elsewhere (Tsou, Blecher, and Meisner, 1981). Here we suggest that it is also incorrect-or at least incomplete - in its understanding of the peasants and China's rural society. It also does not help 
us to understand current developments. If it is true that the rural economy of traditional China can be characterized as a system of precapitalist free-enterprise, the kind of sharing which occurred within the family, the kinship group, the clan, or, to some extent, the village community was very different from the extreme form of egalitarianism which flared up during the peasant rebellions. This radical egalitarianism was nothing less than reaction against the economic inequality produced in the countryside by precapitalist free enterprise. In normal times, the traditional peasants as "small producers" were skillful entrepreneurs rather than extreme egalitarians. The "man from Dazhai," Chen Yonggui himself, was directly quoted to have said: "Only when the peasants are pushed or dragged will they take the socialist road. If left alone, where will they go? Once you relax a little, they will slip toward capitalism" (Renmin ribao, July 9, 1981: 2) Chen's analysis is not too far from the truth.

Hence, the extreme egalitarianism which is now condemned by some intellectuals as a natural trait of the peasants was actually a product of the Chinese revolution, which combined elements from the traditional peasant rebellions and modern socialism. The recent revival of many traditional practices in the countryside and adoption of the responsibility system in an attempt to meet the felt needs and spontaneous demands of the peasants are themselves recognition that the peasantry as a whole does not form the social basis of extreme egalitarianism. They also mark the end of the Chinese revolution in the countryside and its replacement by a program of economic development through the use of some of the practices of the system of precapitalist free enterprise. But this revival is taking place within the context of a new ideology, political order, and economic system. If the regime's rural policy succeeds, the relations of production will not revert to the traditional system of individual farming, nor will they develop into commercialized agriculture in a capitalist form. It will be a curious mixture of a modern collective economy and some of the surviving features of precapitalist free enterprise in the countryside. This may represent the Chinese path to modernization in agriculture in the near future. Although "agrarian socialism" is 
now under strong attack as incompatible with "scientific socialism," it is possible that in the long run a synthesis of these two strands of thought will emerge and represent a creative response to the challenge of modernizing agriculture in China. For egalitarianism was not only rooted in some strands of the Chinese tradition (this point is made in Wang Xiaoqiang, 1980). It is also a modern ideal. The combination of growth with equality is a particularly urgent and inescapable task in a very poor country with a high population-land ratio.

Following a similar line of thinking, we can briefly look at the problem of bureaucratic control in the countryside. During the period of civil and foreign wars, the Party developed not only a mass movement but also a huge bureaucracy. After the victory and through the movements of land reform, cooperativization, and communization, the fighters, activists, and cadres of peasant origin or from small towns and cities in the rural areas staffed the bureaucracy at the levels of the county, commune, and brigade. Indeed, these former peasant rebels and cadres with rural roots led successive mass movements in transforming the countryside in the direction of a greater degree of economic egalitarianism. These mass movements and the elevation of the collective economy to a progressively higher level gave these cadres increasingly great power of control. Their power interests as local leaders and bureaucrats who ran the collective economy must be added to their role as loyal revolutionary Party members as an explanation of the extraordinary pace of the cooperatization movement after 1955 and the excesses in the communization movement. On various occasions Mao undoubtedly wanted to put the responsibility for excesses on the local cadres; there may have been an element of justice in this.

The Cultural Revolution was an attack on the bureaucracy. But the Cultural Revolution itself brought into existence a factional bureaucracy which paralyzed but did not totally destroy the preexisting bureaucratic system. The Dazhai movement increased the control of the leaders at the county, commune, and brigade levels over the production teams and individual peasants. It is probably significant and revealing that the first published 
self-criticism made by Xiyang county occurred after the Party Center sent down a document on the "experience in Xiangxiang county" in Hunan which denounced the practice of upper-level units in using the labor power, funds, and material resources of the production teams without compensation as well as the enormous increase in nonproductive personnel, work, and expenditure (Renmin ribao, July 5, 1981: 7; Xiyang's self-criticism was published on July 21). Shortly thereafter, the Party published another document which condemned the practices of cadres of Xunyi county in maltreating the peasants. Such treatment was frequently the result of cadres trying to prevent the peasants from engaging in selling household sideline products in the rural markets or in other private activities for personal gain (Tsou, Blecher, and Meisner, 1981: 276). Chen Yonggui's leadership style and cadre policy after his seizure of power in Xiyang in 1967 show that even poor and formerly oppressed peasants at the bottom of China's bureaucratic society could consciously or unconsciously take over the political style of the traditional ruling class and succumb to some of the traditional abuses of power after they have risen to positions of authority in a revolution, even if they are simultaneously pushing forward revolutionary, egalitarian, and leftist socioeconomic programs which benefit poor peasants.

Recent changes in the institutions, policies, and practices in the countryside entail a reduction of bureaucratic control and a diminution of local cadres' power. In the context of the acquisition by the peasants, work groups, and production teams of a greater degree of autonomy in managing their own economic affairs, the new system of election with secret ballots and more candidates than positions to be filled may contribute to the development and strengthening of a sense of representation, a new stratum of indigenous leaders, and a tradition of local autonomy. Whether or not this will be the case, there is no doubt that these changes and the current emphasis on the need to adjust institutions, policies, and practices to variations in local conditions will make China's economy, society, and politics much more complex than at any time in its long history. China's fate will hinge on the success or failure of the endeavor to combine this complex system with the goals of political unity and stability and socioeconomic justice in a period of unprecedented change. 


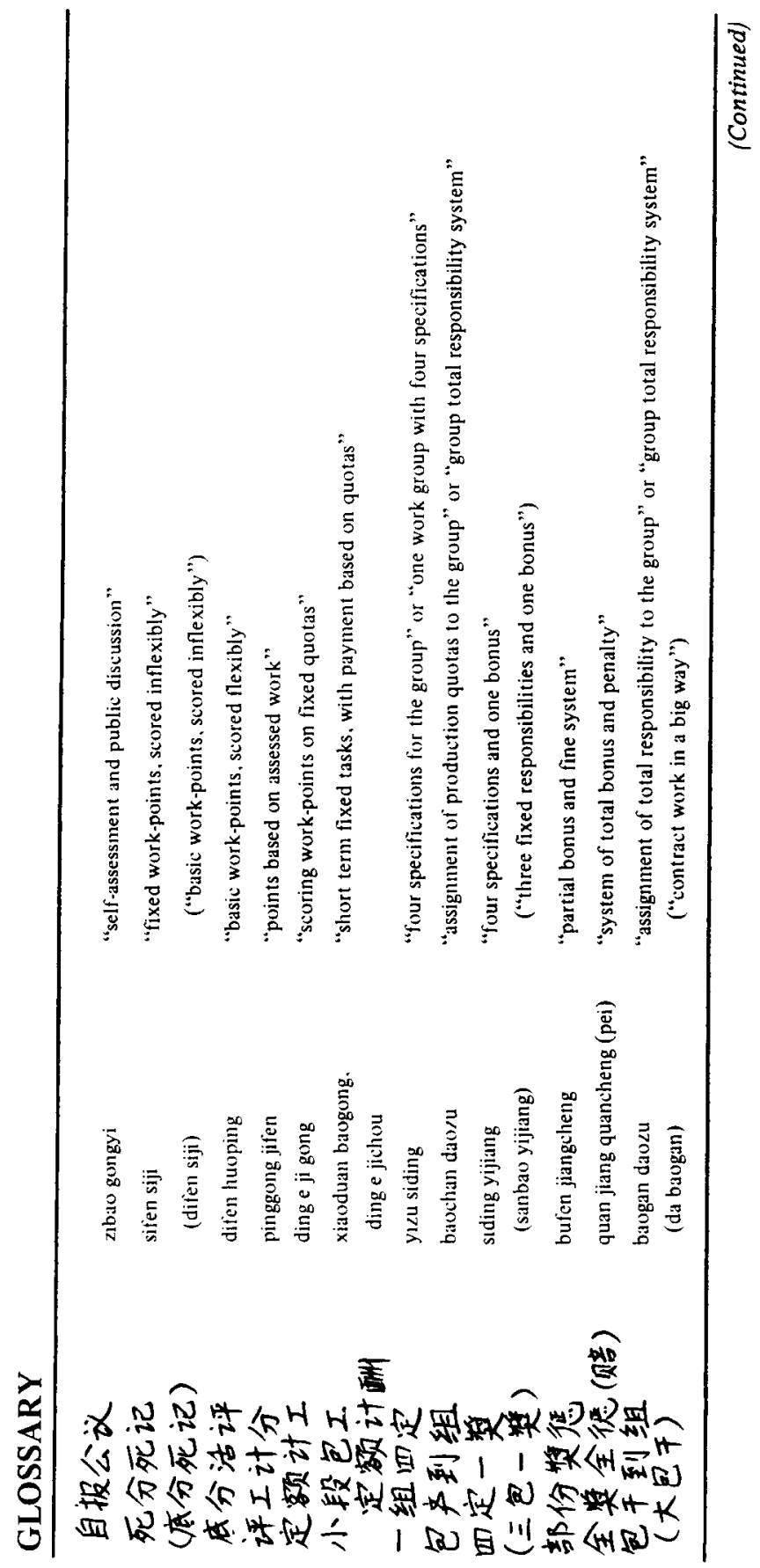




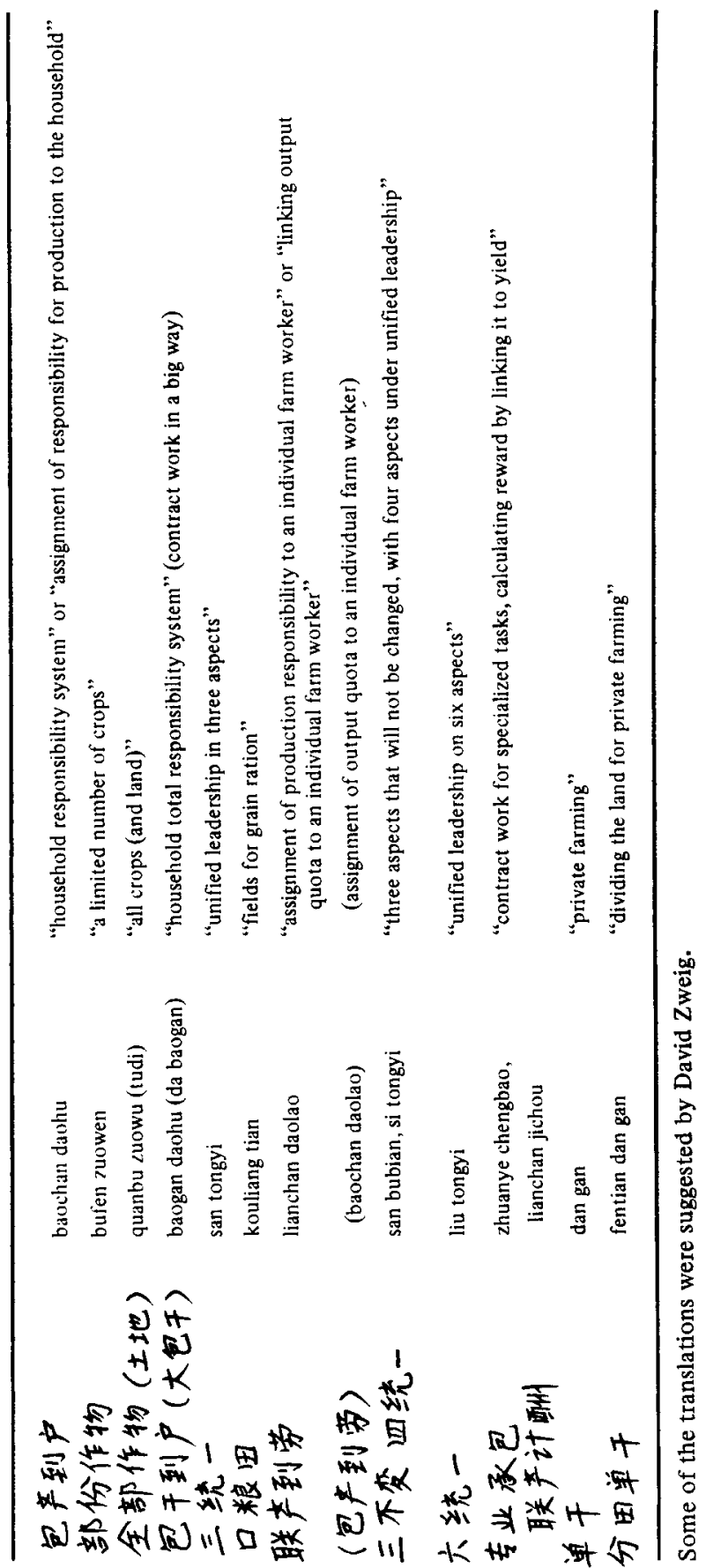




\section{NOTES}

1. There have been proposals for dismantling the commune system. For example, an article in Jingii guanli (1981, no. 1: 10-13) suggests that the present system of "three-level ownership with the team as the basic unit of account" be abandoned and that the production teams be changed into independent agricultural producers' cooperatives-a system used in the period between 1953 and 1956.

2. Article by An Gang et al. in Renmin ribao, July 9, 1981, page 2. An Gang is a deputy editor of the newspaper.

3. This draft has not been published in China in the newspapers or journals surveyed by us.

In his excellent and immensely detailed study, Frederick Crook (1971: 202) translates the term baogong and baochan respectively as "labor contract" and "production contract."

4. In this article the term "district" rather than "prefecture" is used to translate the Chinese term diqu.

5. Before and after the two conferences on agriculture in November and December 1977, Deng Xiaoping twice suggested the revival of the various rural policies proven effective in the past, and pointed out that the Dazhai method of awarding work points could not be popularized and applied everywhere. The election of Chen Yun as a vicechairman of the Party at the Third Plenum made him the most powerful leader in managing China's economic affairs.

6. Banyue tan, no. 8 (April 25, 1981: 4-10). See also Zhonggong yanjiu (March 15, 1981: 110-118). The adoption of this document was immediately followed by the appearance of an editorial in Nongcun gongzuo tongxun 1980, no. 10, and many articles in that journal and two other journals specializing in agriculture-Nongye jingji wenti and Nongye zhishi.

7. In the summer of 1980 , many teams in Sichuan had already allocated more than $10 \%$ of their cultivated land for private plots (Interview in August 1980).

8. The circular allows persons with half-labor power or supplementary labor power to be ziliu ren except during busy agricultural seasons, whereas the report did not mention these restrictions.

9. According to one account, there are more than ten forms of the "responsibility system" (Renmin ribao, editorial, November 1, 1980: 1).

10. Chinese economists and reporters generally classify the responsibility system by using the presence or absence of linkage between reward and yield as the primary criterion. They divide it first into two major categories: One does not link responsibility to yield ( $b u$ lianxi chanliang de shengchan zeren zhi) and the other does (lianxi chanliang de shengchan zeren zhi). See the excellent article by Wang Guichen and Wei Daonan in Jingii Yanjiu, 1981, no. 1, pages 64-67, and the important article by Wu Xiang in Renmin ribao, November 5, 1980, page 2. Instead, we use the level of devolution of responsibility as the primary criterion and the absence or presence of reward-yield linkage as the secondary criterion. Our classification facilitates description of the evolution of the responsibility system and highlights the political problem of the relationship between state and household or individual, while the classificatory scheme used in China calls attention to the economic significance of the change, particularly the role of material incentive.

11. Prior to adoption of the system of self-assessment and public discussion (zibao gongyi) from 1961 to 1963 , there had been 130 to 140 work quotas in Dazhai. 
12. Although "piecework" is the common term applied to the fixed work quota system, in some cases the system might better be called "task rate" since the sizes of individual jobs and time required are relatively great. Compare this to the familiar factory or home-industry piecework in which a worker turns out hundreds of small items in a day, usually the same thing (especially in piece-goods work in the garment industry). Moving cartloads of manure may more appropriately be called piecework.

13. Although the Chinese writers subsumed this form of labor management under the category of responsibility system without reward-output linkage, the use of the work point system in itself establishes a remote linkage between performance and reward because the value of the work point is decided only at the end of the year after the harvest, and it fluctuates with the harvest.

14. The four specifications usually include task, quality standard, time limit, and the work points to be received in exchange. See article by Wang Gengjin and He Jianzhang, Jingji yanjiu, 1978, no. 8, page 18. The provincial authorities in Anhui were among the first to approve this system.

15. This form is classified in China under the category of responsibility system without reward-output linkage.

16. This subtype and all other types of labor management discussed hereafter are classified by Chinese writers as forms of responsibility system with reward-output linkage.

17. In granting this permission, the documents used the term ye keyi after it gave clear permission (keyi) to the system of awarding work points according to work quotas and the system of time work plus appraisal of work done. Thereafter a debate arose at the local level in some areas. One side argued that the best formula was keyi, keyi, geng keyi (is permitted, is permitted, and is all the more permitted). The other side, consisting of the opponents to change, argued that the policy should be keyi, keyi, bu keyi (is permitted, is permitted, and is not permitted) (Renmin ribao, December 24, 1980: 2). Obviously, the proponents of change had won. Moreover, the system of responsibility had by that time extended to the level of a single household and an individual, as we shall see.

18. An article in Honggi expresses reservations about this system. The author fears that it may destroy the system of unified accounting and unified distribution of rewards. He asserts that it should not be classified, without careful examination of its various forms and effects, as one type of "responsibility system." Article by Yu Gudyao, Hongqi, 1980, no. 20 , pages $12-15,35$.

19. The decision on accelerating agricultural development adopted in September 1979 gave permission to employ this system only among single households living in remote hilly areas and where the special needs of certain kinds of sideline production made it desirable.

20. The Xinhua correspondents also contrasted the rapid adoption of this system to the difficulties encountered by the authorities in introducing the Dazhai system of distributing rewards.

21. The ratio between labor and land in this team is low in comparison with many parts of China. Note that a yield per worker of $6,500 \mathrm{jin}$ per year is equivalent to $542 \mathrm{jin}$ per month. If the worker is able to double the rather low output of 168 jin per mu that the quota calls for, the resultant surplus retained is equivalent to a substantial monthly grain ration (kouliang). If the worker could attain yields surpassing 500 jin per $\mathrm{mu}$, he or she would receive a high monthly grain ration plus around $¥ 60$ in cash (figuring 542 additional jin per month at about $¥ 0.11$ per jin). But these yields may not be possible.

22. In Jiangxi, this system is called the "assignment of responsibility for field management to a farm worker and linkage of rewards and bonuses to yields" (Renmin ribao, March 13, 1981: 2). 
23. The work groups, households, and individual farm workers who undertake specialized tasks are known respectively as zhuanye $z u$, zhuanye hu, and zhuanye ren.

24. For use of this system in other localities, see Renmin ribao, April 19, 1981; page 1; May 8, 1981, page 2. Leshan, Sichuan also uses this system. In one case, two cadres of the county were assigned to a team. They were promised a bonus if the production of this team increased (Interview in Leshan, Sichuan, 1980). Some localities in Henan adopted a system under which the subsidies given to cadres will be increased $1 \%$ if the net income of the brigades and teams increases $1 \%$; they will be decreased $1 \%$ if the net income decreases by $1 \%$ (Renmin ribao, August 11, 1981: 2).

25. For Premier Zhao Ziyang's view, see article in Liaowang, 1981, no. 2, pages 2-5. For the latest reports, see articles in Renmin ribao August 22, 1981, page 2 and September 1, 1981, page 2, and articles in Nongye jingii wenti, 1981, no. 6, pages 9-13, 13-17.

26. Mr. Gao Xiubao, a deputy secretary, told Tsou in an interview that even in May and June the Party committee was unwilling to implement fully the decision of the Third Plenum and to criticize ultra-leftist policies and ideas.

27. In Shanxi, in 1980 , there were 120,000 production teams. Of these, $39.8 \%$ had adopted the system of awarding work points according to fixed work quotas for a series of related tasks to be performed over a period of time. In the rest, the teams were divided into work groups and the system of fixing an output quota for each work group was used, locally called lianchan daozu.

28. The officials in Sichuan who gave Tsou these figures noted that this sample was not representative, in that the per capita income from collective sources was Y95.4, far above the Y80.1 for the province as a whole. But they insisted that the per capita income from family sideline occupations was a little more representative.

29. This sample survey puts the net per capita income of peasants from the collective units at Y102, which is much higher than the figure of Y83.4 given in the communique of the State Bureau of Statistics.

30. To be sure, there are statistical problems in manipulating the data. Distortions may result from the use of midpoints of income range categories. The large category of Y 100 to Y 149 given in the 1976 data may in fact overstate the level of inequality in the distribution. The assumption that the highest open-ended categories in Table 4 had a mean of $Y 160$ is arbitrary. Nevertheless, we believe these problems are relatively minor; it is hard for us to imagine a situation under which they could be concealing conceptually significant differences between the levels of inequality in the 1976 and 1979 situations.

31. For a fuller discussion, see Tsou, Blecher, and Meisner (1981: 301-304).

32. The highest yield ever achieved in Xiyang was $271,960,000$ jin in 1979 , when the weather was good and the state raised its prices for grain.

33. The first secretary of the Shaanxi Party committee, Huo Shilian, had expressed his approval of boachan daohu in his inspection trip to one county in Shanxi in March (Renmin ribao, March 26, 1981: 1).

\section{REFERENCES}

AN GANG et al. (1981) "Zhonghua nongye zhenxing youwang" (There is hope for the vigorous development of Chinese agriculture). Renmin ribao (July 9): 2.

Banyue tan. Beijing. 
CROOK, FREDERICK (1971) An Analysis of Work Payment Systems Used in Chinese Mainland Agriculture, 1956 to 1970. Ph.D. dissertation, Tufts University.

Dagong bao. U.S. edition.

Foreign Broadcast Information Service: PRC. FBIS

GONG YUZHI (1981a) “Pipan nongye shehuizhuyi sixiang de zhongyao wenxian" (An important historical document criticizing the ideas of agrarian socialism). Renmin ribao (March 24): 5.

- (1981b) "Yizong gengzheng" (A correction). Renmin ribao (April 10): 5.

Jingi guanli. Beijing.

KUHN, P. A. (1981) "Late Ch'ing views on the polity," pp. 1-18 in Tang Tsou (ed.) Selected Papers from the Center for Far Eastern Studies, No. 4. Chicago: Univ. of Chicago Press.

Liao-wang.

LUO HANXIAN (1980) "Lun nongmin shehui zhuyi” (On peasant socialism). Nongye jingi lunchong 1,1 (November): 58-64.

Nongcun gongzuo tongxun. Beijing.

Nongye jingji wenti. Beijing.

Nongye zhishi. Beijing.

Renmin ribao. Beijing.

TIAN BEIZHI (1981) "Yige zhiming renwu de luoxuan" (The electoral defeat of a wellknown person). Liao-wang 1 (April 20): 20-21.

TSOU, TANG, MARC BLECHER, and MITCH MEISNER (1981) "Policy change at the national summit and institutional transformation at the local level: the case of Dazhai and Xiyang in the post Mao era." Selected Papers from the Center for Far Eastern Studies 4. Chicago: Univ. of Chicago.

WANG GUICHEN and WEI DAONAN (1981) "Lun baochan daohu" (On the household responsibility system). Jingji yanjiu 1 (January): 64-67.

WANG XIAOQIANG (1980) "Nongye shehui zhuyi pipan" (A critique of agrarian socialism). Xinhua yuebao (wenzhai ban) no. 5: 7-13.

WU XIANG (1980) "Yangguandao yu dumuqiao" (Open road and single-log bridge). Renmin ribao (November 5): 2.

YU GUOYAO (1980) "Zenyang kan baochandaohu" (How we view the household responsibility system). Hongqi $20: 12-15,35$.

ZHAN WU and WANG GUICHEN (1981) 'Lun zhuanye chengbao lianchan jichou zerenzhi" (On the responsibility system of contract work for specialized tasks, calculating reward by linking it to yield). Jingji yanjiu 4.

ZHANG JINXING and JIN JIASHENG (1981) "Dazhai xin dangzhibu de dansheng" (The birth of a new Party branch in Dazhai). Liao-wang 1 (April 20): 21-22.

Zhonggong yanjiu. Taibei.

Tang Tsou is a professor in the Department of Political Science of the University of Chicago. He is the author of America's Failure in China, co-editor and co-author of China in Crisis, and editor and co-author of Select Papers From the Center For Far Eastern Studies, No. 4, 1979-1980. 
Marc Blecher is Associate Professor of Government at Oberlin College. He is the author of several articles on Chinese politics and rural political economy, and, with Gordon White, of Micropolitics in Contemporary China. At present he is editing and contributing to a collaborative volume on government, economy, and urban-rural relations in Shulu County, Hebei.

Mitch Meisner is a political scientist specializing in contemporary Chinese politics. He is currently studying law at the University of Michigan. 